\title{
PROTECTION OF CIVILIAN INFRASTRUCTURES
}

\author{
RoberT WAyne Gehring*
}

\section{INTRODUCTION}

For centuries there have been rules to protect some from the effects of war, though invocation in the breach as often as compliance has recognized their existence. Ransom was a common practice of warfare in the Middle Ages. Hauled before a military court on demand of ransom, a captive could claim immunity because of a standing or profession such as cleric, pilgrim, or herald; because he possessed a safe-conduct; or because his capture violated a truce. ${ }^{1}$ Immunizing specific groups, however, implied that war could be waged on all others without restriction.

Later Grotius differentiated the legally permissible and the morally correct. $^{2}$ While it was legally permissible to kill and injure all who were found in the enemy's territory even if they did not bear arms and were not "subjects of him that stirs up the war," 3 certain acts were "devoid of moral justice": 4 "one must take care, so far as is possible, to prevent the death of innocent persons, even by accident." 5 "Furthermore a quite obstinate devotion to one's own party, provided only that the cause is not altogether dishonorable, does not deserve punishment." Though general principles can be drawn from his writing, Grotius proceeded primarily by identification of specific groups against whom war should not be waged, presumably leaving others unprotected. The favored groups were protected in the pursuit of moral justice rather than in recognition of any legal obligation.

With time Grotius's pursuit of moral justice firmed into a legal obligation protecting all persons except combatants:

\footnotetext{
* Major, United States Marine Corps.

1. M. Keen, The Laws of War in The Late Middle Ages 189 (1965). A belief that war (at least among Christian nations) should not disrupt the unity of Christian society inspired these rules, but the cupidity and brutality of armies often rendered the rules as illusory as the unity of Christian society. Id. at 190-91.

2. "In another sense, however, something is said to be permissible, not because it can be done without violence to right conduct and rules of duty, but because among men it is not liable to punishment." H. Grotius, De Jure Belli ac Pacis Libri Tres [The Law of War and Peace], bk. III, ch. IV, sec. II, para. 2, at 642 (Classics of International Law ed. F. Kelsey trans. [of 1646 ed.] 1925) (1st ed. Paris 1624) [hereinafter cited as H. Grotius, The Law of War and Peace]. Also available in 1 The LAW OF War 30 (L. Friedman ed. 1972).

3. H. Grotius, The Law of War and Peace, supra note 2, at 646 (bk. III, ch. IV, sec. VI)

4. Id. at 722 (bk. III, ch. XI, sec. I).

5. Id. at 733 (bk. III, ch. XI, sec. VIII).

6. Id. at 741 (bk. III, ch. XI, sec. XVI, para. 4).
} 
From the moment we are at war, all those who belong to the hostile state become our enemies, and we have a right to act against them as such; but our right to wound and kill being founded on self-defence, or on the resistance opposed to us, we can with justice wound or take the life of none except those who take an active part in the war. ${ }^{7}$

Thus, as the law of war evolved, protection of noncombatants from military attack became the general principle-the reverse of the earlier rules, which had only protected specific groups. The new concerns were qualifications or exceptions to this general principle.

Noncombatants who might be extremely important to the success of their party to the conflict pose a special problem. This early nineteenth-century example from Von Martens's The Law of Nations included the sovereign or members of his family among those to be protected.

[A]ccording to modern manners, 1 . it would be against the laws of war to aim deliberately at the person of a sovereign, or of a prince of the blood royal. 2 . The family of a vanquished sovereign is not only treated with more tenderness than other prisoners of war, but is usually exempted from captivity. 3. In general, sovereigns endeavour to soften the rigours of war in every thing that has no influence with respect to its success; for instance, they grant a free passage to whatever is intended for each other's tables, and, sometimes even presents and compliments pass between them, upon the principle, that it is their states, and not they, that are at war. ${ }^{8}$

As governments became more complex, and more noncombatants were recognized as making a particularly valuable contribution to a war effort, those who might be made prisoners of war expanded in number. By the middle of the nineteenth century, military instructions included guidelines such as the following, written for the United States Army:

The monarch and members of the reigning hostile family, male or female, the chief, and chief officers of the hostile government, its diplomatic agents, and all persons who are of particular and singular use and benefit to the hostile army or its government, are, if captured, on belligerent ground, and if unprovided with a safe conduct granted by the captor's government, prisoners of war. ${ }^{9}$

Today if a person with great power or influence is captured, he is not a prisoner of war, ${ }^{10}$ but he may be isolated from his government and its armed forces by internment or assigned residence to accomplish the same result. ${ }^{11}$

7. G. von Martens, The Law of Nations, bk. VI, ch. III, sec. 4, at 287 (4th ed. W. Cobbett trans. 1829) (1st ed. Gottingen 1788).

8. Id. at 291 (bk. VI, ch. III, sec. 7).

9. U.S. War Dep't, General Orders, No. 100, Instructions for the Government of Armies of the United States in the Field, April 24, 1863, art. 50 [hereinafter cited as Lieber Code], reprinted in 1 The LAW OF WAR, supra note 2, at 168. An interesting sketch of Dr. Francis Lieber, the chief compiler of General Orders No. 100, appears at Davis, Doctor Francis Lieber's Instructions for the Govermment of Armies in the Field, 1 AM. J. INT'L L. 13 (1907).

10. For a description of those persons who may be treated as prisoners of war, see Geneva Convention Relative to the Treatment of Prisoners of War of August 12, 1949, art. 4, [1955] 3 U.S.T. 3316, T.I.A.S. No. 3364 [hereinafter cited as the Third Convention].

11. Geneva Convention Relative to the Protection of Civilian Persons in Time of War of Au- 
While some provisions that deal with the individual "of particular and singular use and benefit to the hostile army or its government" can be found, international conventions rarely address the general class of civil servants who individually are not of great significance, but who as a class are indispensable for the continued operation of their government. ${ }^{12}$ This group and their insurgent counterparts are the concern of this paper. The government bureaucrat, or the parallel figure in an insurgent group, who carries no weapon, wears no uniform, and never fires a shot or otherwise directly injures the adversary can still, through daily attention to administrative detail, contribute mightily to the success of his faction. These bureaucrats man the vital infrastructure of their governments and movements. However, this group was not specifically considered in the Hague Conventions of 1899 and $1907,{ }^{13}$ perhaps because of complete acceptance at the turn of the century of the "cardinal principle of the law of war that military operations must be confined to the armed forces and that the civilian population must enjoy complete immunity."14

Experience in the two World Wars, however, proved that additional rules were needed to protect civilians. ${ }^{15}$ The Geneva Convention Relative to the Protection of Civilian Persons in Time of War of August 12, 1949, ${ }^{16}$ resulted from this experience. The treatment of infrastructure members under that Convention will be explored later.

Events since World War II have established a need both to supplement the Geneva Conventions of August 12, 1949, for the Protection of War Victims ${ }^{17}$ and to modernize many of the rules regulating the actual conduct of hostili-

gust 12, 1949, arts. 41, 42, 48, [1955] 3 U.S.T. 3516, T.I.A.S. No. 3365 [hereinafter cited as the Fourth Convention].

12. One of the few references concerning actions after a territory is occupied, is in the unratified 1874 Declaration of Brussels:

The functionaries and officials of every class who, at the instance of the occupier, consent to continue to perform their duties. shall be under his protection. They shall not be dismissed or be liable to summary punishment (punis disciplinairement) unless they fail in fulfilling the obligations they have undertaken, and shall be handed over to justice, only if they violate those obligations by unfaithfulness.

Declaration of Brussels, August 27, 1874, art. 4, in Record of the Brussels Conference of 1874, PARL. Papers Misc. No. 1, 76 Session Papers 43 (1875) (Gt. Brt.); 65 Brit. \& Foreign State Papers 1871-1874, at 1067-1109 (1881) [hereinafter cited as Brussels Declaration]. The present-day descendant of this provision may be found in the Fourth Convention, supra note 11, at art. 54.

13. See 1 ThE LAW of WAR, supra note 2, at 204-250, 370-397, for a reprinting of the four Hague Conventions of 1899 and the fourteen Hague Conventions of 1907.

14. Commentary, IV Geneva Convention Relative to the Protection of Civilian Persons in Time of War (J. Pictet ed. 1958) [hereinafter cited as Pictet, IV Commentary].

15. Id. at 5 .

16. Fourth Convention, supra note 11 .

17. Hereinafter referred to collectively as the 1949 Conventions. In addition to the Third and Fourth Conventions, cited previously, these are the Geneva Convention for the Amelioration of the Condition of the Wounded and Sick in Armed Forces in the Field of August 12, 1949, [1955] 
ties, last committed to treaty form and ratified in the Hague Conventions of 1907. For that purpose, after several years of preparations by the International Committee of the Red Cross (ICRC) and a series of conferences of experts sponsored by the ICRC, the Diplomatic Conference on the Reaffirmation and Development of International Humanitarian Law Applicable in Armed Conflict was convened in 1974 in Geneva, Switzerland. The Diplomatic Conference, which met in additional sessions annually through 1977, adopted two "Protocols Additional to the Geneva Conventions of 12 August 1949," the first "Relating to the Protection of Victims of International Armed Conflicts"18 and the second "Relating to the Protection of Victims of NonInternational Armed Conflicts." 19 Within the scope of Protocol I are "armed conflicts in which peoples are fighting against colonial domination and alien occupation and against racist regimes in the exercise of the right of selfdetermination" ${ }^{20}$ (CAR conflicts).

This article will explore three bodies of law: (1) rules protecting civilian infrastructures in international conflicts; (2) rules serving the same end in noninternational conflicts; and (3) rules that would apply to CAR conflicts under Protocol I. No attempt will be made to spell out all the rules involved. Instead we shall investigate the protection the law gives civilians from targeting and the protection it gives them while in the power of their enemy. Against that standard we shall inquire whether infrastructure members suffer adverse distinctions based on their infrastructure activities-that is, whether they are exposed to hazards not shared by other civilians.

\section{Attacks upon Civilians in Noninternational Conflicts}

While CAR conflicts are among the international armed conflicts included in Protocol $\mathrm{I}$, in most other respects they more closely resemble noninterna-

3 U.S.T. 3114 , T.1.A.S. No. 3362 [hereinafter cited as the First Convention]; and the Geneva Convention for the Amelioration of the Condition of Wounded, Sick and Shipwrecked Members of Armed Forces at Sea of August 12, 1949, [1955] 3 U.S.T. 3217, T.I.A.S. No. 3363 [hereinafter cited as the Second Convention].

18. Hereinafter referred to as Protocol I. International Committee of the Red Cross, Protocols Additional to the Geneva Conventions of 12 August 1949, at 3-88 (1977) (Protocol I, including Annex I and Annex II) [hereinafter cited as ICRC, Protocol I].

19. Hereinafter referred to as Protocol II. International Commitree of the Red Cross, supra note 18, at 89-101 [hereinafter cited as ICRC, Protocol II]. The Protocols were adopted by the Diplomatic Conference in a Final Act done. June 10, 1977. They were opened for signature by governments on December 12, 1977. The text of both Protocols is reprinted as an appendix to this issue, $42 \mathrm{Law} \&$ Contemp. Prob., Spring 1978, at 203. The text can also be found at 72 Ам. J. INT'L L. 457 (1978).

20. Hereinafter these conflicts will be referred to as CAR conflicts. ICRC, Protocol I, supra note 18 , at art. 1, para. 4 . 
tional conflicts or civil wars, long known for their sanguinary nature. The summation, "[U]ncivilized and inhuman practices were the order of the day," said of the Spanish Civil War, ${ }^{21}$ is apt for a host of civil wars throughout history.

Many explanations have been offered for the unrestrained nature of some noninternational conflicts. As in some of the more famous family feuds in history and literature, revenge and retribution rather than military necessity motivate many actions. ${ }^{22}$ The very personal nature of violence in guerrilla warfare frequently provokes an escalating cycle of revenge and reprisal. ${ }^{23}$ Modern weapons designed more for conflicts between armies on the battlefield than for the small unit engagements of guerrilla warfare contribute to unnecessary violence. ${ }^{24}$ The planes, bombs, and artillery of the government's

21. Thomas \& Thomas, International Legal Aspects of the Civil War in Spain, in ThE INTERNAtional Law of Civil War 111, 135 (R. Falk ed. 1971).

22. "The logic of the conflict is to carry the idea of military necessity beyond all civilized boundaries of humanitarian restraint that have been built into the laws of war over several centuries." Falk, Introduction to The InTERnational LAW OF Crvil War, supra note 21 , at 8.

23. L. Gann illustrates this phenomenon:

From the standpoint of a statistician, a guerrilla operation may be much less destructive than an air raid or a rocket attack. But its moral and psychological effects are likely to be greater. An air raid has an impersonal quality about it. Sirens wail; planes drone overhead; searchlights pierce the sky; flak thunders; bombs whistle; walls shake; houses collapse. But no one knows the name of the pilot who drops the blockbusters. An air raid in some ways appears like a catastrophe of nature. Guerrilla warfare, on the other hand, entails personal violence. Partisan operations usually entail reprisals; reprisals lead to counterreprisals. Terror becomes commonplace until it takes a Goya to paint Los Desastres de la Guerra. Guerrilla warfare thus leaves a heritage of hate that may endure for generations, and may continue when the memories of conventional war have grown dim.

L. Gann, Guerrillas in History 79 (1971).

Examples of the hatred inspired by guerrilla warfare also may be drawn from much closer home. During the American Civil War, General Paine, Union commander in western Kentucky, published the following proclamation: "I shall shoot every guerrilla taken in my district, and if your southern brethren retaliate by shooting a Federal soldier, I will walk out five of your rich bankers, and cotton men, and make you kneel down and shoot them. I will do it, so help me God." R. Bennett, The Black and Tans (1959), quoted in 1 R. Asprey, War in the Shadows: The Guerrilla in History 180 (1975). Civil War era complaints about guerrillas were not limited to Northern commanders. James A. Sedden, the Confederate Secretary of War, reported that "their Rangers, when under inefficient officers and within Confederate lines had come to be regarded as more formidable and destructive to their own people than to the enemy." General Robert E. Lee wrote:

Experience has convinced me that it is almost impossible under the best officers even, to have discipline in these bands of partisan rangers, or to prevent them from becoming an injury instead of a benefit to the service, and even where this is accomplished, the system gives license to many deserters and marauders who assume to belong to these authorized companies and commit depredations on friend and foe alike. Another great objection to them is the bad effect upon the discipline of the army from the constant desire of the men to leave their commands and enjoy the great license allowed in these bands. With the single exception mentioned, I hope the order will be issued at once, disbanding the companies and battalions serving in this department.

P. Bordwell, The Law of War Between Belligerents 80-81 (1908).

24. Although no statistics of rising casualty rates due to the use of modern weapons in 
forces are not ideal weapons for ferreting out a guerrilla squad in a village. The availability of explosives in many easy-to-use forms facilitates terrorist use of timed bombs and other destructive devices unable to distinguish between the member of government military forces, the government bureaucrat, and the innocent passerby. Some radical philosophers of recent years, rejecting the view that war is an evil to be endured so that peace may be restored, ${ }^{25}$ have glorified violence inflicted in pursuit of a particular cause ${ }^{26}$ and even its "therapeutic effects" on the participants. ${ }^{27}$

Not all force directed against civilians in noninternational conflicts is the product of brutal, uncaring, or irrational minds. In some cases it is carefully planned policy implemented in the hopes of achieving victory more quickly. Attacking the enemy through the morale of its supporting civilians is, histori-

noninternational conflicts have been compiled, the effect of such weapons in international conflicts is clear.

In World War I, 5 percent of the killed were civilians; in World War II, 50 percent; in the Korean War, 60 percent; and according to the estimates of the U.S. Government for killed and wounded in the Vietnam war, 70 percent.

The reason for this is plain, the acceptance of indiscriminate weapons and indiscriminate targets. Fearful weapons of mass destruction are now regarded as lawful and permissible, while the Hague Conventions are still in the stage of outlawing dum-dum bullets and the dropping of explosives from balloons. Targets are found acceptable which if attacked, will inevitably bring massive suffering, starvation and loss of life to the civilian population.

Subcomm. on Int'l Organizations and Movements of House for. Affalrs Comm., Human Rights in the World Community: A Call for U.S. Leadership, 93d Cong., 2d Sess. 35 (March 27, 1974).

25. Most succinctly, "War is an evil activity to be endured in order that peace may be regained." Draper, Military Necessity and Humanitarian Imperatives, 12 MIL. L. \& L. WAR Rev. 129, 135 (1973). "The ultimate object of all modern war is a renewed state of peace." Lieber Code, supra note 9, at art. 29, reprinted in 1 THE LAW of WAR, supra note 2, at 164 .

An eloquent, if more extensive, statement is in Regis Debray's words in his own defense at trial in Bolivia:

Revolutionary war is not a question of individuals facing individuals-everyone has a family, parents, sons, loved ones, a childhood. They are but mere representatives of two irreconcilable orders. These acts of war are the fruit of social, economic and moral antagonisms existing independently of the will of the actors and preceding them. No one has created these antagonisms, and no one can take them away, but they indeed should be surmounted and settled. Naturally, the tragedy is that we do not kill objects, numbers, abstract or interchangeable instruments, but, precisely, on both sides, irreplaceable individuals, essentially innocent, unique for those who have loved, bred, esteemed them. This is the tragedy of history, of any history of any revolution. It is not individuals that are placed face to face in these battles, but class interests and ideas; but those who fall in them, those who die, are persons, are men. We cannot avoid this contradiction, escape from this pain.

R. Debray, Strategy for Revolution 207-208 (1970).

26. "In terms of ethics, both forms of violence [revolutionary and reactionary] are inhuman and evil-but since when is history made in accordance with ethical standards? To start applying them at the point where the oppressed rebel against the oppressors, the have-nots against the haves, is serving the cause of actual violence by weakening the protest against it." Marcuse, $R \ell$ pressive Tolerance, in R. Wolff, B. Moore, \& H. Marcuse, A Critique of Pure Tolerance 103 (1965), quoted in Prophetic Politics III (M. Cranston ed. 1970).

27. See Zolberg, Frantz Fanon, in Prophetic Politics, supra note 26, at 126, 129-130. 
cally, the justification most often offered for military attacks upon civilians. "Bringing home the war to the enemy" so that the people will pressure their leaders to surrender is a familiar rationale. General Sherman explained the effects of this tactic during the American Civil War:

I attach more importance to these deep incisions into the enemy's country, because this war differs from European wars in this particular; we are not only fighting hostile armies, but a hostile people, and must make old and young, rich and poor, feel the hard hand of war, as well as their organized armies. I know that this recent movement of mine through Georgia has had a wonderful effect in this respect. Thousands who have been deceived by their lying newspayers to believe that we were being whipped all the time now realize the truth, and have no appetite for a repetition of the same experience. ${ }^{28}$

Besides attacking the general morale of the population, the intent of attacks involving civilians may be to condition behavior by punishing specific instances of help to the adversary, ${ }^{29}$ to provoke the other party into overreaction and self-alienation from the population, ${ }^{30}$ or covertly to place blame upon the other party for some atrocity. By such tactics each party to the conflict seeks to isolate its enemy from the general population on which all must ultimately depend. ${ }^{31}$

\section{A. Resources of Government and Insurgents and the Civilian Infrastructure}

The disparity in physical and administrative resources between a government and a guerrilla insurgent group also encourages attacks upon civilians. The government may begin the struggle with a nearly overwhelming superiority in organized military force-a near monopoly on heavy military equipment as well as a large numerical advantage in uniformed personnel equipped with lighter weapons. The government also has an existing adminis-

28. P. Bordwell, supra note 23, at 79. Early in the American Civil War, both sides entertained an intention to apply the established laws of war during the hostilities. However, the late Professor Quincy Wright found that as the war continued there was a tendency on both sides "to accept the thesis . . . that the object of war could best be achieved by attacking the civilian morale of the enemy directly." Wright, The American Civil War, in The International Law of Civil WAR, supra note 22, at 30, 65. Despite examples of these tactics on both sides, Professor Wright concluded that both sides generally observed the standards set by the Lieber Code. Id. at 56 .

Similar to General Sherman's statement are General J. Franklin Bell's words from the Philippines at the turn of the century: "[I]t is necessary to make the state of war as insupportable as possible . . . by keeping the minds of the people in such a state of anxiety . . that living under such conditions will soon become unbearable." N. Leites \& C. Wol.f, Rebellion and Authority 97 (1970).

29. N. Leites \& C. Wolf, supra note 28, at 99-110. Such a policy is designed to punish undesired behavior while protecting favorable behavior from retribution by one's adversary; it requires accurate intelligence so that one's actions do not appear arbitrary.

30. Id. at $112-17$.

31. One authority has defined guerrilla revolution as an armed struggle to isolate one's opponent from the people. J. Bell, The Myth of the Guerrilla 99 (1971). 
trative structure to supply these armed forces as well as to collect taxes, implement various programs, and enforce laws. The government's military forces are only the cutting edge of a vast and complex organism.

That the national power of a state depends on much more than the mere size of its standing armed forces has long been recognized. The factors affecting national power have been categorized in terms of control over people: the more skilled, loyal, and numerous the population, the better the control over economic and geographic resources and over institutional arrangements (internal as well as external structures and processes for decisionmaking). ${ }^{32}$ The means by which the government exercises this control-its "population utilization" system ${ }^{33}$-include, besides its military forces, the political structure, the police, and the bureauracy. ${ }^{34}$ The individual members of this system are the civilian politicians, police, and bureaucrats (tax collectors, provincial officials, judicial officials, and other civil servants) who provide the daily contact between the average citizen and his government. They settle disputes between citizens, enforce the government's laws and administer its programs, draft the young men, collect the taxes, and receive the average citizen's complaints or petitions. The bureaucracy also includes those employed at higher and more abstract levels of the governmental hierarchy. These clerks and Cabinet Ministers are responsible for organizing the overall activities of the government

32. M. McDougal \& F. Feliciano, Law and Minimum World Public Order 307-308 (1961). Of course, the population is equally important to the insurgents. Mao Tse-tung declared of the relationship "that should exist between the people and the troops," that "[t]he former may be likened to water and the latter to the fish who inhabit it." Implementing that principle were "The Three Rules and the Eight Remarks," which served as a code for the Eighth Route Army:

Rules:

1. All actions are subject to command.

2. Do not steal from the people.

3. Be neither selfish nor unjust.

Remarks:

1. Replace the door when you leave the house.

2. Roll up the bedding on which you have slept.

3. Be courteous.

4. Be honest in your transactions.

5. Return what you borrow.

6. Replace what you break.

7. Do not bathe in the presence of women.

8. Do not without authority search the pocketbooks of those you arrest.

Mao Tse-tung, On Guerrilla Warfare 92 (S. Griffith trans. 1961). Che Guevara also emphasized the care with which the local population must be treated. C. Guevara, Guerrilla Warfare 6, 42, 53, 55 (1971). A similar concern is present in several of the questions and answers of another Latin American revolutionary, General Alberto Bayo. A. Bayo, Ciento cincuenta preguntas A UN GUERRILLERO 99-102 (1960).

33. "Population utilization" is a utilitarian term deliberately chosen by Andrew Scott to illustrate that "winning the hearts and minds" is not the primary objective; more than a popularity contest is at stake. A. Scort, InSURGenCy 58-61 (1970). Population utilization is one of the six input factors by which he analyzes insurgencies. The others are leadership, organization, manpower, intelligence, and logistics. Id. at 51-58.

34. Id. at 96. 
- everything from advancing the argricultural self-sufficiency of the nation to coordinating intelligence information to combat subversion to the system that procures supplies for the nation's armed forces. All these civilians, though they never carry a weapon or fire a shot in anger, are as involved in a government's efforts to combat insurgency as any rifleman pushing through a steamy jungle on a combat patrol.

The insurgents' position normally will be the reverse of the government's. The insurgents may start long on ideas, goals, and indignation but short on men, money, and bullets. When acquired, these material resources must be transported where they can be used. Secrecy must cloak the insurgent efforts so that the government cannot focus its tremendous power advantage on the fragile initial stages of insurgency. As prominent former revolutionary Regis Debray explained, guerrillas need mobility and flexibility to survive. ${ }^{35}$ Secrecy is their indispensable resource.

Important as secrecy and concealment are in the field, they are even more important for the underground organization supporting those military forces. Insurgents depend on an underground organization or infrastructure for all forms of support-recruiting; finances; supplies of ammunition, medicine, food, weapons, clothes, and intelligence. Even if the insurgents receive significant assistance from foreign sources, they must arrange clandestine transport into the country. This supporting infrastructure requires many more people than those actually involved in combat. ${ }^{36}$

35. R. Debray, Revolution in the Revolution? 61-63 (B. Ortiz trans. 1967). This is tactical secrecy. Too much secrecy, however, will conceal the very existence of an insurgent movement from the population, allowing the movement to wither on the vine. Some action for propaganda purposes is necessary. Thus, the Irgun in 1944 publicly called for revolt and an immediate transfer of power to a Provisional Hebrew Government. M. Begin, The Revolt 43 (1951). Debray emphasizes that the destruction of troop transport or public execution of a police torturer is more effective propaganda than 100 public speeches. R. Debray, Revolution in the RevoluTION, supra.

36. A. Molnar, Undergrounds in Insurgent, Revolutionary, and Resistance Warfare 41 (1963). In addition to these common support functions of the civilian infrastructure, Molnar's work provides a much more complete list of the role of the civilian underground during a revolution:

(1) organizes the revolutionary movement;

(2) controls and coordinates all revolutionary activities;

(3) provides internal administrative functions for the revolutionary movement, such as recruitment, training, indoctrination, finances, logistics, communications, security;

(4) conducts subversion of the existing government's personnel and institutions;

(5) conducts psychological operations, both propaganda and actions (e.g., popular fronts) among the uncommitted people of the nation, and among important foreign nations;

(6) establishes "shadow" governments which are to assume power when the revolutionaries win;

(7) provides intelligence information for the revolutionary movement;

(8) conducts sabotage of sources of governmental control over the people of the nation, including assassination of political leaders; disruption of economic institutions and processes, communication, transportation, armed forces, police, and militia, and "all those things which make the lot of the people a happier one." 
The importance of those who collect funds for the insurgent organization's operations, gather and analyze information about government forces, procure the necessary supplies from within or without the country, organize the delivery of the supplies to the military forces of the insurgency, and organize the recruitment of members of the local population cannot be overestimated. While these functions may be performed by military members of the movement, in many cases military training is not required or is not even an asset in their performance. One experienced observer, Sir Robert Thompson, believes that so long as the supporting organization remains intact, killing insurgents in the field is largely useless: the casualties will be replaced by new recruits. ${ }^{37}$ A study of characteristics that determined the outcome in fortyfour revolutions of this century found the single most important factor was not battlefield success but whether the government was successful in interdicting the insurgents' supply of arms and ammunition. ${ }^{38}$ The government cannot rely upon success on the field of battle to bring its ultimate victory. It must starve the insurgent military forces by uncovering and neutralizing the civilian infrastructure supporting those military forces.

\section{B. Attacks Upon the Civilian Infrastructure}

Given a similar disparity of resources on the international scene, a nation would rarely attack a more powerful neighbor: its armed forces would be gobbled up far faster than they could be replenished and augmented. The insurgent, however, aims not at the military defeat of his adversary's armed forces in the field and the formal surrender of the government but at the weakening and collapse of the government from within. This goal is more attainable, though slower to attain.

Both factions ultimately depend upon the general population. The civilian bureaucracy and its counterpart insurgent infrastructure are the tie between their respective fighting forces and the population. If the government cannot find the elusive insurgent military forces, or if the insurgent is too weak to defeat the government's military forces in direct confrontation, the infrastructure members of the adversary afford a tempting target: break that connecting link and the opposing fighting force should wither and die.

The government's civilian bureaucrats are a target more vulnerable than its military forces, and their destruction can lead to the government's collapse. Insurgents may first attack the most unpopular provincial officials to

(9) provides escape and evasion networks for members of the movement.

Id. at 40. Again, the concern of this article is governmental civil servants and their insurgent counterparts. Underground members engaged in spying and sabotage can no more expect normal civilian treatment than if they were performing the same functions in an international conflict.

37. N. Leites \& C. WoLf, supra note 28 , at 77.

38. D. Condit, Modern Revolutionary Warfare 120 (1973). 
gain favor with the local population. Later attacks may be aimed at the best officials, "those who are efficient without being obnoxious," 39 to encourage mediocrity and inefficiency in the government's service. For example, it is reported that most of the 600 people killed in Rhodesia from December, 1972 , through the early months of 1976 were black family, village, and tribal chiefs who supported the white government. ${ }^{40}$ Similarly, it was reported that the cream of Vietnam village officialdom had been killed by 1957: The Communists regarded these leaders as a "key element in the struggle." 41

On the other hand, the government must uncover and neutralize the insurgent infrastructure if military success on the battlefield is ever to be followed by political victory. The Phoenix program in Vietnam was variously alleged to involve the conversion, capture, or assassination of members of the Viet Cong infrastructure. ${ }^{42}$ Amnesty International recently reported that Rhodesia's police and security forces routinely employ torture to gain information from black Africans suspected of aiding guerrillas. ${ }^{43}$

Given these pressures, it is unrealistic to expect either faction totally to ignore the bureaucracy or infrastructure of the other. Such a result is not required by law even in international conflicts. The law seeks not to prohibit all methods of war other than direct confrontation between military forces but to channel the means used into those less destructive of the life and property of civilians. Other means of influencing civilians are still available to the parties to the conflict.

\section{Protection of Civilian Infrastructure in International Conflicts}

This section briefly explores the foundations of the law of war and the rules derived therefrom for the protection of civilians in international armed conflicts. Those rules will be examined to ascertain whether governmental civil servants are given the same protection as other civilians, both before and after capture by their enemy.

\section{A. Basic Principles of Applicable Law}

Military necessity, humanity, and chivalry are the basic principles supporting the law of war. ${ }^{44}$ Remnants of chivalry that survive in the modern law

39. N. LeITES \& C. Wolf, supra note 28 , at 117.

40. Wash. Post, March 29. 1976, \& A. at 9, col. 1 .

41. B. Fall, The Two Vietnams 281 (1964), quoted in N. Leites \& C. Wolf, supra note 28, at 117 .

42. See discussion and citations in LAW AND Responsibility IN Warfare (P. Trooboff ed. 1975), at 45, 75-76, 100 .

43. Wash. Post, March 30, 1976, § A, at 10, col. 3.

44. M. McDougal \& F. Feliciano, supra note 32, at 521-22, 522 n.l. 
of war are largely subsumed in the other two principles and need not concern us separately. ${ }^{45}$

Humanity in war has often been denounced as a surrender to puerile sentimentality, which actually lengthens war and its horrors. Thus, General Von Hindenburg declared, "One cannot make war in a sentimental fashion. The more pitiless the conduct of the war, the more humane it is in reality for it will run its course all the sooner." 46 Of more recent vintage is Che Guevara's advice that "circumstances and the will to win will often oblige him [the guerrilla] to forget romantic and sportsmanlike concepts."47

Such criticism misconceives the modern formulation of humanity, which prohibits only that degree or kind of violence "not actually necessary for the purpose of the war." 48 This modern formulation focuses attention on its corre-

\section{Id. at 522 .}

"Chivalrous conduct, a personal rather than a state deterrent, lost its force with the passing of the aristocratic officer and his replacement during the transition period by the businessman in uniform. For a brief period in World War I it appeared that chivalrous conduct would form a basis for a new law of air warfare. However, such expectations were not fulfilled." DEP'T OF THE Army, Pamphlet No. 27-161-2, 2 International Law 15 (1962).

46. Adler, Targets in War: Legal Considerations, in 3 ThE VIETNAM War and INTERnational LAW 282, 293 (R. Falk ed. 1972).

47. C. Guevara, supra note 32 , at 8 . One of the most eloquent statements running counter to this view was offered in historian and publicist Charles Francis Adams's address honoring the memory of Robert E. Lee. Adams, a member of the Union forces who became a general in the last stages of the war, delivered this address in 1903:

On the one side, it is contended that warfare should be strictly confined to combatants, and its horror and devastations brought within the narrowest limits. . . But, on the other hand, it is insisted that such a method of procedure is mere cruelty in disguise; that war at best is Hell, and that true humanity lies in exaggerating that Hell to such an extent as to make it unendurable. By so doing, it is forced to a speedy end. . .

What was the result? Hell was indeed let loose; but so was Hate. Was the war made shorter? No! Not by an hour! It was simply made needlessly bitter, brutal, and barbarous. ...

As an American, as an ex-soldier of the Union ... I rejoice that no such hatred attaches to the name of Lee. . . . No more creditable order ever issued from a commanding general than that formulated and signed at Chambersburg by Robert E. Lee as, towards the end of June, 1863, he advanced on a war of invasion. "No greater disgrace," he then declared, can "befall the army and through it our whole people, than the perpetration of barbarous outrages upon the innocent and defenceless. Such proceedings not only disgrace the perpetrators and all connected with them, but are subversive of the discipline and efficiency of the army, and destructive of the ends of our movement."

War is Hell, Address by Charles Francis Adams, 13th Annual Dinner of the Confederate Veterans' Camp of New York (January 26, 1903), quoted in Taylor, Foreword to THE LAW of WAR, supra note 2 , at $\mathbf{x x}$.

48. U.S. Dep't of the Army, Field Manual No. 27-10, Rules of Land Warfare, para. 4(b) (October 1940), quoted in 10 M. Whiteman, Digest of International Law, at 299 (1968). The present edition is U.S. Dep't of the Army, Field Manual No. 27-10, The Law of Land WarFARE (July 18, 1956) [hereinafter cited as ARMY ManUaL].

The equivalent manual of the U.S. Navy states, "The principle of humanity prohibits the employment of any kind or degree of force not necessary for the purpose of the war, i.e., for the partial or complete submission of the enemy with the least possible expenditure of time, life, and physical resources." U.S. Dep't of The Navy, NWIP No. 10-2, Law of Naval Warfare, sec. 220(b) (July 1959) [hereinafter cited as Navy ManUal], quoted in $10 \mathrm{M}$. Whiteman, supra, at 300. 
late, military necessity, to determine the degree and kind of force permitted to belligerents in warfare. This modern formulation of humanity is not mere sentimentality, and it does not lack substantive content because it is not applied in isolation. Humanity stands with military necessity as the foundation for the law of war; neither is designed to stand alone. Rather, the two should weave a seamless web, so that what is not permitted by one is prohibited by the other.

Military necessity has been defined as that principle which "permits a belligerent to apply only that degree and kind of regulated force, not otherwise prohibited by the laws of war, required for the partial or complete submission of the enemy with the least possible expenditure of time, life and physical resources." 49 Two elements common to most modern formulations of military necessity are: (1) a compelling requirement that the military actions in question be taken if the war objectives (the submission of the enemy in modern formulations) are to be achieved, ${ }^{50}$ and (2) recognition that the rules of war

The equivalent manual of the U.S. Air Force states, "Complementing the principle of necessity and implicitly contained within it is the principle of humanity which forbids the infliction of suffering, injury or destruction not actually necessary for the accomplishment of legitimate military purposes." U.S. Dep't of the Air Force, Air Force Pamphlet No. 110-31, International Law-The Conduct of Armed Conflict and Air Operations, para. 1-3.a(2), at 1-6 (1976) [hereinafter cited as Air Force Manual].

The statement in the equivalent British manual is: "The principle of humanity, according to which kinds and degrees of violence which are not necessary for the purpose of war are not permitted to a belligerent." United Kingdom War Office, The Law of War on Land, Being Part III of the Manual on Military Law, sec. 3 (1958) [hereinafter cited as British Manual].

49. Navy Manual, supra note 48, at sec. 220(a), quoted in $10 \mathrm{M}$. Whiteman, supra note 48 , at 300. This modern formulation is not a twentieth-century innovation. Very similar terminology may be found in the Lieber Code of 1863: "Military necessity, as understood by modern civilized nations, consists in the necessity of those measures which are indispensable for securing the ends of the war, and which are lawful according to the modern law and usages of war." Lieber Code, supra note 9, at art. 14, reprinted in 1 THE LAW OF WAR, supra note 2, at 161.

An equivalent passage from the current Army Manual defines military necessity as "that principle which justifies those measures not forbidden by international law which are indispensable for the complete submission of the enemy as soon as possible." Army MaNual, supra note 48, at 4, para. 3(a). The Air Force Manual describes military necessity as: "the principle which justifies measures of regulated force not forbidden by international law which are indispensable for securing the prompt submission of the enemy, with the least possible expenditures of economic and human resources." AIR Force Manual, supra note 48, at para. 1-3(a)(1), at 1-5-1-6.

The British Manual defines military necessity as "the principle that a belligerent is justified in applying compulsion and force of any kind, to the extent necessary for the realisation of the purpose of war, that is, the complete submission of the enemy at the earliest possible moment with the least possible expenditure of men, resources, and money." BrITISH MANUAL, supra note 48, at sec. 3.

50. The phrasing of this compelling requirement varies from author to author. One may use such terms as "urgent need, admitting of no delay," Downey, The Law of War and Military Necessity, 47 Ам. J. INT'L L. 251,254 (1953). Another may say “immediately indispensable," O'Brien, Legitimate Military Necessity in Nuclear War, 2 Y.B. of WORLd Polity, 35, 46-49, 67 (1960), quoted in $10 \mathrm{M}$. Whiteman, supra note 48 , at 316 . Still others may be satisfied with an unqualified "indispensable" (one of several definitions of military necessity found in Dunbar, Military Necessity in War Crimes Trials, 29 Brit. Y.B. INT'L L. 442-46 (1952), quoted in 10 M. Whiteman, supra note 48, 
prohibit some forms of military action even in the face of a compelling requirement.

An implication of the compelling requirement is that the kind and degree of force used must be relevant and proportionate to the end sought; ${ }^{51}$ otherwise the need will not be compelling. This point was vividly expressed during the Nuremberg trials:

Military necessity has been invoked by the defendants as justifying the killing of innocent members of the population and the destruction of villages and towns in the occupied territory. Military necessity permits a belligerent, subject to the laws of war, to apply any amount and kind of force to compel the complete submission of the enemy with the least possible expenditure of time, life and money. In general, it sanctions measures by an occupant necessary to protect the safety of his forces and to facilitate the success of his operations. It permits the destruction of life of armed enemies and other persons whose destruction is incidentally unavoidable by the armed conflicts of the war; it allows the capturing of armed enemies and others of peculiar danger, but it does not permit the killing of innocent inhabitants for purposes of revenge or the satisfaction of a lust to kill. The destruction of property to be lawful must be imperatively demanded by the necessities of war. . . It does not admit the wanton devastation of a district or the willful infliction of suffering upon its inhabitants for the sake of suffering alone. ${ }^{52}$

at 308) or merely with the terms "necessary" and "prompt realization" (M. McDougaL \& F. Feliciano, supra note 32 , at 72).

Interestingly, the Air Force Manual, the most recent of the authorities cited, expressly subdivides military necessity into four elements:

(i) that the force used is capable of being and is in fact regulated by the user; (ii) that the use of force is necessary to achieve as quickly as possible the partial or complete submission of the adversary; (iii) that the force used is no greater in effect on the enemy's personnel or property than needed to achieve his prompt submission (economy of force), and (iv) that the force used is not otherwise prohibited.

Air Force Manual, supra note 48, at para. 1-3.a(1), at 1-6.

51. McDougal states that military necessity authorizes "such destruction, and only such destruction, as is necessary, relevant, and proportionate to the prompt realization of legitimate belligerent objectives." M. McDougal \& F. Feliciano, supra note 32, at 72. O'Brien formulates military necessity in the following terms: "Military necessity consists in all measures immediately indispensable and proportionate to a legitimate military end, provided that they are not prohibited by the laws of war or the natural law, when taken on the decision of a responsible commander, subject to judicial review." O'Brien, supra note 50, at 48 . In addition, both McDougal and $O^{\prime} B$ rien note the breadth of actions permitted if necessity, relevancy, and proportionality are tied only to the "complete submission of the enemy." Thus, McDougal refers to "legitimate belligerent objectives" and spells out an analytical framework by which their legitimacy is to be determined. O'Brien also refers to a "legitimate military end." Id.

The ends of the generality with which these authors deal need not concern us here, since armed conflicts against "colonial domination, and alien occupation and against racist regimes" are apparently granted full legitimacy as belligerent objectives by article 1.2 of Protocol I. ICRC, Protocol I, supra note 18 .

52. The Hostage Case (U.S. v. List), in 11 Trials of War Criminals Before the Nuernberg Military Tribunals 759, 1253-54 (1950), quoted in $10 \mathrm{M}$. Whiteman, supra note 48, at 301. There is a striking similarity between the words of the International Military Tribunal at Nuremberg and the words of the Lieber Code, written almost a century earlier:

Military necessity admits of all direct destruction of life or limb of armed enemies, and of other persons whose destruction is incidentally unavoidable in the armed contests of the war; it allows of the capturing of every armed enemy, and every enemy of importance to the hostile government, or of peculiar danger to the captor; it allows of all de- 
The second shared element is the subordination of the compelling requirement to specific prohibitions in the law of war. At various times in the past it has been argued that military necessity, in stringent circumstances, authorized an inherent exception to otherwise absolutely phrased prohibitions contained in the law of war. The German doctrine of Kriegsraison argued that the rules of prohibition were not obligatory "when the circumstances are such that the attainment of the object of the war and the escape from extreme danger would be hindered by observing the limitations imposed by the laws of war."53

This contention should have been laid to rest during the war crimes trials following World War II. This declaration made during the Krupp trial reasserted the absolute nature of prohibitions in the law of war.

It is an essence of war that one or the other side must lose and the experienced generals and statesmen knew this when they drafted the rules and customs of land warfare. In short these rules and customs of warfare are designed specifically for all phases of war. They comprise the law for such emergency. To claim that they can be wantonly-and at the sole discretion of any one belligerent-disregarded when he considers his own situation to be critical, means nothing more or less than to abrogate the laws and customs of war entirely. ${ }^{54}$

This subordination of the compelling requirement to some of the specific prohibitions in the law of war transforms the doctrine of military necessity

\footnotetext{
struction of property, and obstruction of the ways and channels of traffic, travel, or communication, and of all withholding of sustenance or means of life from the enemy; of the appropriation of whatever an enemy's country affords necessary for the subsistence and safety of the army, and of such deception as does not involve the breaking of good faith either positively pledged, regarding agreements entered into during the war, or supposed by the modern law of war to exist. Men who take up arms against one another in public war do not cease on this.account to be moral beings, responsible to one another and to God.
}

Lieber Code, supra note 9, at art. 15 (emphasis in original), reprinted in 1 THE LAW OF WAR, supra note 2, at 161 .

Military necessity does not admit of cruelty-that is, the infliction of suffering for the sake of suffering or for revenge, nor of maiming or wounding except in fight, nor of torture to extort confessions. It does not admit of the use of poison in any way, nor of the wanton devastation of a district. It admits of deception, but disclaims acts of perfidy; and, in general, military necessity does not include any act of hostility which makes the return to peace unnecessarily difficult.

Id. at art. 16.

53. 4 F. von Holtzendorff, Handbuch des Völkerrechts 254, 248-255 (1889), quoted in 2 J. Westlake, International Law 126 (2d ed. 1913). See also citations in 2 L. Oppenheim, InterNATIONAL LAw, at 231 n.6 (7th ed. 1952); Che Guevara's statement at note 47 supra and accompanying text.

54. The Krupp Trial, in 10 U.N. War Crimes Comm'n, Law Reports of Trials of War CrimInAls, 64, 139 (1949), quoted in $10 \mathrm{M}$. Whiteman, supra note 48, at 302. The Army Manual states, "Military necessity has been generally rejected as a defense for acts forbidden by the customary and conventional laws of war inasmuch as the latter have been developed and framed with consideration for the concept of military necessity." Army Manual, supra note 48, at 4, para. 3(a). See also Navy Manual, supra note 48, at sec. 220(a) n.8; Air Force Mandal, supra note 48, at para. 1-3.a.(1). 
from mere repetition of the military principle of economy of force into a foundation for law. It is not the purpose of the law of war to permit all violence necessary to achieve success under any conceivable set of circumstances. As stated in the Hague Regulations of 1907, "The right of belligerents to adopt means of injuring the enemy is not unlimited." 55

\section{B. Protection of Civilians}

\section{Immunity from Targeting}

One level of generalization below the principles of humanity and military necessity is the "generally recognized rule of international law that civilians must not be made the object of attack directed exclusively against them." The Navy Manual's articulation of the rule is more detailed:

Under customary international law individuals who do not form a part of the armed forces and who refrain from the commission of all acts of hostility must be safeguarded against injury not incidental to military operations directed against combatant forces and other military objectives. In particular, it is forbidden to make noncombatants the object of a direct attack by the armed forces of a belligerent, if such attack is unrelated to a military objectuve. Attack for the sole purpose of terrorizing the civilian population is also forbidden. ${ }^{57}$

Such a rule is the logical consequence of the principles of humanity and military necessity. While a hostile civilian population may represent a potential source of manpower and material resources for the opposition, the immediacy of such a threat cannot compare with that represented by the opposing military force. Similarly, once that military force is overcome, its supporting civilian population can be controlled without the destruction inherent in further military attacks. Thus, attacks upon civilians are not a compelling requirement for defeat of the enemy. ${ }^{58}$

55. Hague Convention -No. IV Respecting the Laws and Customs of War on Land, October 18, 1907, Annex, Regulations Respecting the Laws and Customs of War on Land. art. 22, 36 Stat. 2277, at 2301, T.S. No. 539 [hereinafter cited as Hague Convention No. IV]. Very similar language is used in article 33.1 of Protocol 1: "In any armed conflict, the right of Parties of the conflict to choose methods or means of warfare is not unlimited." ICRC, Protocol I, supra note 18, at art. 33(1).

56. ARMy ManUal, supra note 48, at 16, para. 25.

57. Navy Manual, supra note 48, at sec. 221 (b). The British Manual is the most succinct: "Civilian inhabitants.. may not be killed or wounded, nor as a rule taken prisoner." BrITISH MANUAL, supra note 48, at sec. 88. Again, compare with the Lieber Code of 1863: "the una. med citizen is to be spared in person, property, and honor as much as the exigencies of war will admit." Lieber Code, supra note 9, at art. 22, reprinted in 1 THE LAW OF WAR, supra note 2, at 162. See also Air Force Manual, supra note 48, at para. 1-3.a(2).

58. For example, World War II area bombing in populated areas has been severely criticized for several reasons, including its strengthening of the enemy's resistance. "Area attacks, while perhaps justifiable as retaliation, were a complete violation of the principles of war strategically. They vitiated forces rather than concentrating them against the decisive point, they were 
World War II presented a mighty challenge to this theory. ${ }^{59}$ The size of the conflicting forces, the life-or-death nature of the struggle, the organization of entire nations to support their respective military forces and their concomitant vulnerability to blockade and contraband practices, the compelling need to weaken the enemy's armed forces before battle and interdict them from supplies and reinforcements during battle, and the availability of air power to pursue these ends on a scale hitherto unimagined, strained the principle of civilian immunity to the utmost. ${ }^{60}$ For example, the British Directive

uneconomical of force, and they strengthened the enemy will to resist." R. Higham, Air Power: A Concise History 132 (1972). See also U.S. Strategic Bombing Survey, Overall Report (EuROPEAN WAR) 108 (1945).

59. Of course, the challenge by no means originated with World War II. See General Sherman's comment made during the American Civil War, at text accompanying note 28 supra. Sometimes it may appear that the opposing armed force can most effectively be weakened by indiscriminate attack upon the supporting civilians to destroy their morale. The only real intent, however, is to isolate the armed forces from their support. Once that objective is recognized, targets other than population centers will be chosen to enable a concentration of force upon the particular objective in accord with strategic principles. Thus, attacks will be made upon transportation and communications centers, stockpiles of supplies, production facilities for war matériel-all targets that can be attacked more efficiently and effectively than the supporting civilians. See authorities cited at note 58, supra.

60. George Aldrich, Deputy Legal Adviser, U.S. Department of State, said in 1973:

[W]e have seen ... all too clearly a general acceptance of the view that modern war is aimed, not merely at the enemy's military forces, but at the enemy's willingness and ability to pursue its war aims. Thus, in World War II, the enemy's will to fight and his capacity to produce weapons were primary targets, and saturation bombing, blockade of food supplies, and indiscriminate terror weapons, such as the German V bombs, were all brought to bear on those targets. In Vietnam, political rather than military objectives were even more dominant. Both sides had as their goal not the destruction of the other's military forces but the destruction of the will to continue the struggle. To that end the United States bombed and mined ports, rivers, and other lines of communication without invading North Vietnam, and our enemies launched rockets against cities, assassinated government officials and other influential civilians, and tortured prisoners to obtain propaganda statements, without any hope of destroying American military strength.

George Aldrich, Remarks made during panel on Human Rights and Armed Conflict at the 67th Annual Meeting of the American Society of Internationl Law (April 13, 1973), reprinted in AM. Soc'y of Int'l L., Proceedings of the 67th Annual Meeting, at 141, 147 (1973).

Professor Baxter long ago cited three factors as contributions to this trend: (1) the conflict over ideology that often motivates contemporary conflicts, (2) an increasing technological difficulty in differentiating between military and nonmilitary objectives, and (3) frequent voluntary participation of the civilian as a guerrilla or member of the underground or secret agent, requiring stringent control of his activities. Baxter, So-Called "Unprivileged Belligerency": Spies, Guerrillas, and Saboteurs 28 BRIT. Y.B. INT'L L. 323, 325-26 (1951).

Professor Farer finds a progressive erosion of the main principles of the law of war "because of the conviction that an important ingredient of victory is destruction of the enemy's industrial base. Efforts to destroy that base, to eliminate the communications and power infrastructure and the industries which they support, lead to such gross devastation of urban areas that the distinc. tion between direct and incidental injury to the civilian population loses most of its significance." Farer, Illicit Means for the Conduct of Armed Conflicts, 12 MIL. L. \& L. WAR REV. 153, 156 (1973).

Professor Lauterpacht ascribes the deterioration of the "time-honored distinction between members of the armed forces and civilians" to five developments appearing during and since World War II: (1) growth in the number of combatants; (2) growth in the number of noncombatants engaged in war preparations; (3) the development of aerial warfare; (4) economic measures; 
of October 29, 1942, on air warfare, after spelling out various measures to avoid undue loss of civilian life in the vicinity of military targets, concluded:

$[N]$ one of the foregoing rules should apply in the conduct of air warfare against German, Italian, or Japanese territory, except that the provisions of the Red Cross Conventions were still to be observed, "for consequent upon the enemy's adoption of a campaign of unrestricted air warfare, the Cabinet have authorized a bombing policy which includes the attack on enemy morale."61

Writing in 1945, Stowell referred to "the inviolability or immunity of civilians from the effects of military operations" as an "irrational and sentimental popular opinion" whose rational significance had been greatly weakened, if not entirely destroyed, by the conditions of modern warfare. "[I]t has become logical to bring pressure to bear on the civilian population in order that they may induce the government to yield," he continued; in addition, the civilians are a legitimate target because "practically every phase of national activity contributes to the support and success of modern war." 62 While not arguing that the civilian population had become a legitimate target, Nurick asserted that the civilian-military distinction had been "so whittled down by the demands of military necessity that it has become more apparent than real." 63 After lengthy analysis, he concluded:

How then is the noncombatant immune from attack? He is legally subject to almost unrestricted artillery and naval bombardment. If he lives in a besieged locality, he may legally be starved or bombed. If he lives in a country which does not grow enough food to support its population, a blockade can legally starve him to death. If he lives in an important city, he is subject to bomb and robot attack of the most catastrophic nature. True, in many cases, he may not be the intended subject of attack, but under modern methods of waging war that gives him little protection. Where does this leave the "fundamental" doctrine that a noncombatant is relatively immune from attack?"

As World War II receded into history, however, rather than abandoning the legal distinction between military and civilians in targeting, the scope of conventional restrictions in warfare has expanded. ${ }^{65}$ This expansion has been

(5) the advent of totalitarian states, which dominate the individual and regiment the economy so as to render artificial, for many purposes, the distinction between the fighting forces and the civilian population. 2 L. OPPEnheIM, supra note 53, at sec. 57(a). More recently, Lauterpacht recognized that, in time of war, increased state control of the economy is not limited to totalitarian states. British Manual, supra note 48 , at sec. 86 n.(2)(a)(v).

61. Quoted in 2 W. Craven \& J. Cate, The Army Air Forces in World War II 240, reprinted in icRC Draft Rules for the Limitation of the Dangers Incurred by the Civilian Population IN TIME OF WAR 163 (1956).

62. Stowell, The Laws of War and the Atomic Bomb, 39 AM. J. INT'L L. 784, 785 (1945).

63. Nurick, The Distinction Between Combatant and Noncombatant in the Law of War, 39 AM. J. INT'L L. 680 (1945).

64. Id. at 696 .

65. Although the British Directive of October 29, 1949, note 61 supra and accompanying text, set a different standard for bombing enemy territory than for military targets in occupied territory of allies, it still required compliance with the Red Cross Conventions. 
slowest in regulating actual combat. For example, the Fourth Convention contains only a few provisions that specifically protect civilians or civilian institutions during combat operations. ${ }^{66}$ A major part of Protocol I, however, seeks to expand this protection. Similar progress is also evident in municipal orders regulating armed forces. ${ }^{67}$

\section{Protection While in the Power of the Enemy}

Much more rapid progress was made in extending protections for civilians under the power of their enemy during occupation of their homeland. The definition of "war crimes" used in prosecutions after World War II included "murder, ill-treatment or deportation to slave labor or for any other purpose of civilian population of or in occupied territory." 68 The 1949 Conventions vastly expanded the protections afforded those left in the wake of combat operations, including civilians in occupied territory or caught in the enemy's territory at the outbreak of war.

The principles of humanity and military necessity provide strong support for this concern for civilians left in the wake of combat. When military necessity cannot justify targeting civilians during combat, it is even less able to justify attacks upon civilians once they have been captured or once their territory is occupied. During combat the imperative of overcoming the enemy's armed forces, while not permitting direct attack upon civilians, does permit considerable incidental damage to civilians found in the vicinity of military targets. Once battle has passed, however, the imperative demands of combat are replaced by the more prosaic concerns of efficient administration of occupied territory and security of one's armed forces against any threat emanating from the occupied territory.

66. Fourth Convention, supra note 11 , at art. 15 (neutralized zones); id. at arts. 18-22 (civilian hospitals, medical personnel, medical convoys, and aircraft).

67. See U.S. Military Assistance Command, Vietnam, Directive No. 525-13, Rules of Engagement for the Employment of Firepower in the Republic of Vietnam (May, 1971), reprinted in 121 Cong. REC. \$ 9877-9901 (daily ed. June 6, 1975). The directive requires that "all possible means will be employed to limit the risk to the lives and property of friendly forces and civilians. In this respect, a target must be clearly identified as hostile prior to making a decision to place fire on it." Id. at para. 6(a). There are several annexes to the directive, which provide more detailed rules for specific types of weapons. See, e.g., id, at Annex, Rules of Engagement-Surface Weapons Excluding Naval Gunfire, para. 3(a); id. at Annex, Rules of Engagement-Fixed Wing Air Operations.

68. The complete definition is as follows:

(b) WAR CRIMES: namely, violations of the laws or customs of war. Such violations shall include, but not be limited to, murder, ill-treatment or deportation to slave labor or for any other purpose of civilian population of or in occupied territory, murder or illtreatment of prisoners of war or persons on the seas, killing of hostages, plunder of public or private property, wanton destruction of cities, towns or villages, or devastation not justified by military necessity.

Charter of the International Military Tribunal, August 8, 1945, art. 6(b), 59 Stat. 1544, 1546, E.A.S. No. 472, reprinted in I THE LAW of WAR, supra note 2 , at 885,887 . 
Before its territory is occupied, the civilian population serves as a reservoir of manpower and matériel for its armed forces. When the occupation separates the civilian population from its armed forces, this threat disappears. With the change from a combat environment to an administration and security environment, actions are impelled not by military necessity but by those more long-term considerations of law and order. There is time for due process and consideration of individual culpability before executing punitive measures. Thus, there is no compelling requirement for the destruction of life and property, at least before granting minimal legal procedural rights. ${ }^{69}$

\section{Forfeiting Immunity and Criminal Liability}

Civilians pay a big price for their legal immunity from targeting in combat and their protection during occupation. By participating in hostilities they forfeit their privileged status. They must not commit hostile acts. Impotency is the price of immunity.

The principles of humanity and military necessity permit nothing less. There is no compelling requirement to attack the civilian, because he represents no physical threat in himself. If a civilian violates this assumption, takes his rifle from the wall and comes out of his door shooting, he forfeits his legal protection and may be attacked as may any group of uniformed and armed men. Still more importantly, his act threatens the privileged status of other civilians as the jittery enemy soldiers become apprehensive of all civilians. A ci-

69. "No sentence shall be pronounced by the competent courts of the Occupying Power except after a regular trial." Fourth Convention, supra note 11, at art. 71 . Article 71 further requires that the accused shall be "promptly informed, in writing, in a language which they understand, of the particulars of the charges preferred against them, and shall be brought to trial as rapidly as possible." Additionally, the protecting power must be informed of the proceedings concerning charges involving a death penalty or imprisonment of two years or more at least three weeks before the first hearing. Under article 72 the accused have the right to present evidence, to call witnesses, to be assisted by a qualified advocate or counsel of their choice, and to be aided by an interpreter. Under article 73 the convicted person has the right of appeal provided for by the laws applied by the court, and he must be informed of that right.

The Lieber Code of 1863 insisted that "the unarmed citizen is to be spared in person, property, and honor as much as the exigencies of war will admit." Lieber Code, supra note 9, at art. 22, reprinted in I THE LAW OF WAR, supra note 2, at 162. The Code also provides that "protection of the inoffensive citizens of the hostile country is the rule; privation and disturbance of private relations are the exceptions." Id. at art. 25. In a postwar discussion of occupation practices. Lauterpacht indicated that "such private subjects [of belligerent states] as do not directly or indirectly belong to the armed forces. ... . ought to be safe as regards their life and liberty, provided they behave peacefully and loyally." 2 L. OPpen heim, supra note 53, at 204, 206 (sec. 57). The British Manual insists that "Civilian inhabitants, on the other hand, may not be killed or wounded, nor as a rule taken prisoner." British MANUAL, supra note 48 , at sec. 88 . A recent implementation of this rule may be found in U.S. Military Assistance Command, Vietnam, Directive No. 381-46, Military Intelligence Combined Screening of Detainees [persons who have been detained but whose final status has not yet been determined] (December 27, 1967). This provided that the detainees be released and returned to the place of their capture if they were determined to be innocent civilians. Id. at Annex A, para. 5.a(4). 
vilian who commits some act of violence only permitted a uniformed soldier ${ }^{70}$ forfeits his immunity under the law of war and may be punished for his act. ${ }^{71}$

70. Besides exposing the combatant to targeting, lawful combatant status authorizes the commission of acts of violence that would be criminal if subject to municipal law. Pictet's Commentary divides precapture acts for which prisoners of war may be prosecuted into two groups: first, acts not connected with the state of war-common-law offenses committed either within or without the territory of the prosecuting power (which are not the concern of this article); and second, acts connected with the war. Under the latter category, the Commentary discusses only violations of international law: crimes against peace, war crimes, and crimes against humanity. J. DE PreUx, Commentary, ili Geneva Convention Relative to the Treatment of Prisoners of War 417-422 (J. Pictet ed. 1960) [hereinafter cited as Pictet, III Commentary]. Draper also addresses himself solely to the question of war crimes committed by prisoners of war prior to their capture. G. Draper, The Red Cross Conventions 64 (1958). This follows from the principle of customary international law that members of belligerent forces are immune from the municipal law of the countries in which they fight. The legality of their actions is to be measured only by international law. Thus, the Lieber Code provided: "There exists no law or body of authoritative rules of action between hostile armies, except that branch of law of nature and nations which is called the law and usages of war on land." Lieber Code, supra note 9, at art. 40, reprinted in 1 THE LAW OF WAR, supra note 2, at 166 . "All municipal law of the ground on which the armies stand, or of the countries to which they belong, is silent and of no effect between armies in the field." Id. at art. 41 .

This result does not necessarily obtain, however, for prisoners of war who are members of organized resistance movements, qualifying for prisoner of war status under article $4 \mathrm{~A}(2)$ of the Third Convention who are captured while fighting in occupied territory of their own country. Under article 64 of the Fourth Convention, supra note 11, an occupying power may "subject the population of the occupied territory to provisions which are essential . . . to ensure the security of the Occupying Power, of the members and property of the occupying forces or administration, and likewise of the establishments and lines of communication used by them." Note that article 64 does not restrict the application of these provisions to "protected persons" under the Fourth Convention, but permits their application to the entire population. While "population" may not include members of a hostile power's military forces dropped within the occupied territory to organize its resistance, "population" would appear to include those normally resident within the territory occupied who are now members of the organized resistance movement. Providing that the requirements of article 99 of the Fourth Convention, supra note 11, are met-that after capture these resistance members are not prosecuted for various war acts committed before the promulgation of the occupying power's regulations forbidding such acts-it would appear that members of organized resistance movements fully complying with the laws of war as well as the other requirements for prisoner of war status under art. $4 \mathrm{~A}(2)$ of the Third Convention, supra note 10 , may still be prosecuted as criminals and tried for violations of the occupying power's security reg. ulations. They must, of course, still receive the benefits of the Third Convention as required by article 85 of the Third Convention.

71. "It is one of the purposes of the laws of war to ensure that an individual who belongs to one dass or the other [military or civilian] shall not be permitted to enjoy the privileges of both. Thus he must not be allowed to kill or wound members of the army of the opposing belligerent and subsequently, if captured, to claim that he is a peaceful civilian." BRITISH MANUAL, supra note 48, at sec. 86. The Navy Manual also conditions the safeguarding of civilians from injury not incidental to military operations upon their refraining "from the commission of all acts of hostility." Navy Manual, supra note 48, at sec. 221 (b). See also Air Force Manual, supra note 48, at paras. 3-3(b).

With reference to guerrilla warfare and the applicability of the law of war to civil conflict, Professor Baxter has said that there are "several common threads of policy-that innocent civilians should be protected . . . and that persons should not be allowed to assume the guise of innocent civilians as a cover for their belligerent activities." H. Levie, When Battle Rages, How Can Law Protect? 73 (The 14th Hammarskjöld Forum, Working Paper and Proceedings, 1971) (state- 
Civilians may also be criminally punished for various acts committed after the battle has passed ${ }^{72}$ that endanger the security of the occupying power. Of course, punishment of a civilian for hostile acts committed either before or after occupation can only be administered after a trial containing essential minimum safeguards. ${ }^{73}$ Once the hostile civilian is captured, his hostile acts cease. No longer is there any compelling requirement for immediate action: his submission has been achieved. Punishment for his past acts is not a question of military necessity but of retribution, future protection of the captor power, and deterrence of similar harmful acts by his fellow countrymen. These are the motivations in any criminal justice system. Hence, the erring civilian must be provided the procedural rights considered essential in a criminal justice system. ${ }^{74}$

ment of Professor Baxter) [hereinafter cited as When Battle RaGes]. "Protected persons shall not be arrested, prosecuted or convicted by the Occupying Power for acts committed or for opinions expressed before the occupation, or during a temporary interruption thereof, with the exception of breaches of the laws and customs of war." Fourth Convention, supra note 11, at art. 70.

At least today a trial is required. Fourth Convention, supra note 11, at art. 71. This was not always the case in the past, as this passage from the Lieber Code indicates:

Men, or squads of men, who commit hostilities, whether by fighting, or inroads for destruction or plunder, or by raids of any kind, without commission, without being part and portion of the organized hostile army, and without sharing continuously in the war, but who do so with intermitting returns to their homes and avocations, or with the occasional assumption of the semblance of peaceful pursuits, divesting themselves of the character or appearance of soldiers-such men, or squads of men, are not public enemies, and therefore, if captured, are not entitled to the privileges of prisoners of war, but shall be treated summarily as highway robbers or pirates.

Lieber Code, supra note 9, at art. 82, reprinted in 1 ThE LAw of WAR, supra note 2, at 173. A different rule is promulgated in modern practice: "If . . they [civilian inhabitants] commit or attempt to commit hostile acts, they are liable to punishment, after a proper trial." British MANUAL, supra note 48 , at sec. 88 . The Army Manual contains several relevant provisions:

Persons, such as guerrillas and partisans, who take up arms and commit hostile acts without having complied with the conditions prescribed by the laws of war for recognition as belligerents... are, when captured by the injured party, not entitled to be treated as prisoners of war and may be tried and sentenced to execution or imprisonment.

Army Manual, supra note 48 at 34 , para. 80 . "Persons who, without having complied with the conditions prescribed in the laws of war for recognition as belligerents . . commit hostile acts about or behind the lines of the enemy are not to be treated as prisoners of war and may be tried and sentenced to execution or imprisonment." Id. at para. 81. "Persons in the foregoing categories who have attempted, committed, or conspired to commit hostile or belligerent acts are subject to the extreme penalty of death because of the danger inherent in their conduct. Lesser penalties may, however, be imposed." Id. at para. 82.

With their memory of German occupation still fresh, the Danish delegation to the diplomatic conference that wrote the 1949 Geneva Conventions proposed that prisoner of war status be extended to "civilian persons acting in lawful defence, or participating in the defence of their native land in the event of illegal aggression or occupation." This proposal was rejected. Pictet, III COMMENTARY, supra note 70 , at 56 .

72. Fourth Convention, supra note 11, at arts. 64, 68; Army Manual, supra note 48, at 99, para. 248.

73. Fourth Convention, supra note 11 , at art. 71 .

74. A nineteenth-century incident that traditionally has been considered an example of 


\section{Hostile Acts}

\section{a. During Combat}

While publicists and governmental instructions to armed forces frequently discuss the requirement that civilians refrain from hostile acts if they wish to preserve their immunity from targeting or subsequent criminal punishment, ${ }^{75}$ they less frequently discuss the outer limits of "hostile acts." Yet this question gravely concerns our civil servant who, albeit peacefully, supports the war effort of his government. Certainly the civilian who shoots passing enemy soldiers with his hunting rifle, secretes a bomb in their encampment, or commits other acts directly and intentionally causing death or injury to his enemy commits a hostile act. But does the civil servant who designs the specifications for a battle tank or supervises the procurement of napalm for the armed forces do the same? The Army Manual gives a nonexhaustive list of unarmed "hostile acts": "Such acts include, but are not limited to, sabotage, destruction of communications facilities, intentional misleading of troops by guides, liberation of prisoners of war, and other acts not falling within Articles 104 and 106 of the

necessity in the law of self-defense provides an excellent analogy here as well. In 1873 the Virginius, headed for Cuba with men and arms to support an insurrection, was seized by Spanish authorities on the high seas. Fifty-three of the crew and passengers were summarily tried by court-martial on charges of piracy and were shot before a British warship arrived and halted the proceedings. Both the United States (the state of registry of the Virginius) and Great Britain (some of whose subjects were among those summarily tried) protested. Of particular interest are the grounds asserted by the British, who did not contest the right of Spain to seize the Virginius or to detain the personnel. The British protested only the summary trial given the British subjects, arguing that there was no longer any imminent necessity once they had been seized-hence regular trial proceedings rather than summary proceedings would have sufficed to prosecute any violations of law that occurred. 2 J. Moore, Digest of International. Law, sec. 309, at 895-903 (1906); Gehring, Defense Against Insurgents on the High Seas, 27 JAG. J. 317, 336-37 (1973).

An equally fine summary of the law of war distinguishing between actions permitted with regard to enemy forces and the limitations on treatment of captured personnel, both military and civilian, may be found in the military judge's instructions in U.S. v. Calley:

The killing of resisting or fleeing enemy forces is generally recognized as a justifiable act of war, and you may consider any such killing justifiable in this case. The law attempts to protect those persons not actually engaging in warfare, however; and limits the circumstances under which their lives may be taken.

Both combatants captured by and noncombatants detained by the opposing force, re. gardless of their loyalties, political views, or prior acts. have the right to be treated as prisoners until released, confined, or executed, in accordance with law and established procedures, by competent authority sitting in judgment of such detained or captured individuals. Summary execution of detainees or prisoners is forbidden by law.

U.S. v. Calley, 46 C.M.R. 19, 26, 22 C.M.A. 534, 541 (1973) (instructions of the Military Judge to the court members), reprinted in 2 THE LAw of WAR, supra note 2, at 1703, 1721.

75. See references cited at note 71 supra

"According to a generally recognized customary rule of International Law, hostile acts on the part of private individuals, not organized as compact movements operating under a responsible authority, are not acts of legitimate warfare, and the offenders may be punished in accordance with International Law." 2 L. OPPEnheim, supra note 53, sec. 57, at 206. 
Uniform Code of Military Justice and Article 29 of the Hague Regulations."78 The acts listed affect an enemy directly rather than indirectly through support of the civilian's own forces. That is consistent with the requirement of the Army Manual that the acts be committed about or behind the lines of the civilian's enemy. ${ }^{77}$

\section{b. While in the Power of the Enemy}

\section{After occupation, the scope of punishable acts widens considerably:}

Subject to the restrictions imposed by international law, the occupant can demand and enforce from the inhabitants of occupied territory such obedience as may be necesary for the security of its forces, for the maintenance of law and order, and for the proper administration of the country. It is the duty of the inhabitants to carry on their ordinary peaceful pursuits, to behave in an absolutely peaceful manner, to take no part whatever in the hostilities carried on, to refrain from all injurious acts toward the troops or in respect to their operations, and to render strict obedience to the orders of the occupant. $^{78}$

76. Army Manual, supra note 48, at 34, para. 81. Article 104 of the Uniform Code of Military Justice punishes aid or attempts to aid the enemy. 10 U.S.C. $\$ 904$ (1956). Prosecution for this offense presumably requires some tie of loyalty to the United States, based on U.S. nationality or residence, or some duty to obey regulations and refrain from injury to the United States, such as the duty that exists for a resident of territory occupied by the United States. Article 106 of the Uniform Code of Military Justice and article 29 of the Hague Regulations embody the traditional rule punishing spying. Note that punishment for the acts under paragraph 81 of the Army Manual requires that these ties of loyalty or obedience be present before prosecution is permitted.

77. ARMy ManUal, supra note 48 , at para. 81 .

78. Id. at 158 , para. 432. See Fourth Convention, supra note 11 , at art. 64. However, the occupying power, unless absolutely prevented, must respect the laws in force in the country. Hague Convention No. IV, supra note 55, at Annex, art. 43; Fourth Convention, supra note 11, at art. 64. The occupying power is permitted to alter, repeal, or suspend:

a. Legislation constituting a threat to its security, such as laws relating to recruitment and the bearing of arms.

$b$. Legislation dealing with political process, such as laws regarding the rights of suffrage and of assembly.

c. Legislation the enforcement of which would be inconsistent with the duties of the occupant, such as laws establishing racial discrimination.

Army ManUal, supra note 48, at 143, para. 371. See Fourth Convention, supra note 11, at art. 27, para. 4.

Restrictions on the occupying power's exercise of authority do exist. The death penalty is lim. ited to cases of espionage, serious acts of sabotage against military installations of the occupying power, or intentional offenses causing the death of one or more persons, provided such offenses were punishable by death under the law of the occupied territory in force before occupation. Fourth Convention, supra note 11, at art. 68. The United States and several other countries reserved the right to impose the death penalty without regard to whether the offense was previously punishable by death in the territory occupied. Fourth Convention, supra note 11, at Reservations Made at the Time of Signature of the Geneva Conventions for the Protection of War Victims of August 12, 1949. Other offenses "solely intended to harm the Occupying Power" that do "not constitute an attempt on the life or limb of members of the occupying forces or administration, nor a grave collective danger, nor seriously damage the property of the occupying forces or administration or the installations used by them," are punishable by internment or simple imprisonment, "provided the duration of such internment or imprisonment is proportionate to the 
Though the scope of punishable acts is broader after occupation than before, the primary concern is still to prevent acts of civilians directly threatening the life or limb of occupying personnel or the security of important installations. While other acts directed solely against the occupying power may be punished, the more severe penalties cannot be levied on them. Acts that afford only incidental damage to the occupying power, while motivated by some other concern, do not come within the scope of these provisions. Their legality and punishment will presumably depend on the criminal laws surviving from before the occupation.

This result also is consistent with the basic principles of humanity and military necessity. The occupying power requires special protection only against acts directed specifically against, or otherwise seriously threatening, its continued administration of the territory it occupies. Normally, attacks on the occupying power's personnel or on installation vital to its security pose the most immediate threat. Acts not specifically intended to harm the occupying power or its personnel do not present a compelling requirement for extraordinary measures beyond the scope of the criminal justice system that survives from before the occupation. Our civil servant is protected from punishment for his pre-occupation support of his government's armed forces, but he may be punished as a criminal if he clandestinely continues to aid them after occupation.

\section{Nonpunitive Restrictions on Movement}

Even in the absence of any offense, a civilian may be subjected to internment or assigned residence if "absolutely necessary" for the security of a detaining power, ${ }^{79}$ or if necessary for "imperative reasons" for the security of an occupying power ${ }^{80}$ Hostile acts committed before the occupation that do not violate the laws and customs of war, or other incidents that demonstrate the capacity of a particular individual who cannot be convicted of any offense to pose a serious threat to the security of the occupying power are the objects of this provision. But the occupying power may take only measures justified by and impelled by its security. The Commentary on article 42 of the Fourth Convention states by way of example:

Subversive activity carried on inside the territory of a Party to the conflict or actions which are of direct assistance to an enemy Power both threaten the

offence committed. Furthermore, internment or imprisonment shall, for such offences, be the only measure adopted for depriving protected persons of liberty." Id.

79. Fourth Convention, supra note 11 , at art. 42.

80. Id. at art. 78. Pictet's discussion emphasizes that each case must be considered separately; there can be no collective measures. Pictet, IV Commentary, supra note 14, at 367 . The legal pigeonhole differs, but the basic authority provided has not changed since the Lieber Code, which permitted the detention of "persons who are of particular and singular use and benefit to the hostile army or its government," requiring that they be treated as prisoners of war. Lieber Code, supra note 9, at art. 50, reprinted in 1 ThE LAW OF WAR, supra note 2, at 168. 
security of the country; a belligerent may intern people or place them in assigned residence if it has serious and legitimate reason to think that they are members of organizations whose object is to cause disturbances, or that they may seriously prejudice its security by other means, such as sabotage or espionage; the provisions of Article 5 of the present Convention may also be applied in such cases.

On the other hand, the mere fact that a person is a subject of an enemy Power cannot be considered as threatening the security of the country where he is living; it is not therefore a valid reason for interning him or placing him in assigned residence. To justify recourse to such measures the State must have good reason to think that the person concerned, by his activities, knowledge or qualifications, represents a real threat to its present or future security.

The Convention stresses the exceptional character of measures of internment and assigned residence by making their application subject to strict conditions; its object in doing this is to put an end to an abuse which occurred during the Second World War. All too often the mere fact of being an enemy subject was regarded as justifying internment. Henceforward only absolute necessity, based on the requirements of state security, can justify recourse to these two measures, and only then if security cannot be safeguarded by other, less severe means. All considerations not on this basis are strictly excluded. ${ }^{81}$

The Commentary on article 78 of the Fourth Convention refers back to article 42 and adds:

In occupied territories the internment of protected persons should be even more exceptional than it is inside the territory of the Parties to the conflict; for in the former case the question of nationality does not arise. That is why Article 78 speaks of imperative reasons of security; there can be no question of taking collective measures; each case must be decided separately. ${ }^{\mathbf{8 2}}$

\section{Status of Civilian Infrastructure Members}

The governmental civil servants of the parties to an international àrmed conflict are generally protected equally with other civilians from the effects of combat. While their service may locate them in closer proximity than other civilians to military forces or military objectives, increasing their exposure to incidental damage, they suffer no adverse legal distinction. The normal administrative activity of civil servants is not a hostile act for which civilians forfeit their immunity from targeting under the law of war, even when they perform duties in support of their own fighting forces. After occupation they may be subjected to internment or assigned residence if their special skills or experience make them potentially very dangerous to the occupying power ${ }^{83}$ They cannot, however, be punished for acts otherwise legal that were performed in support of their own military forces prior to occupation. ${ }^{84}$

81. Pictet, IV CommentaRy, supra note 14 , at 258.

82. Id. at $\mathbf{8 6 7 .}$

83. Fourth Convention, supra note 11 , at art. 78.

84. Id. at art. 70 . 


\section{Parties Regulated}

Most parties to an international armed conflict are governed in their conduct of hostilities by the international law of war. This, however, is more a question of definition than one of logic, since an armed conflict is international when it is between two or more states or other subjects of international law. The principles of humanity and military necessity, the general prohibition on targeting civilians, the more specific rules of the Hague Regulations of 1907, and the general principles of the Geneva Convention Relative to the Treatment of Prisoners of War of July 27, 1929, ${ }^{\mathbf{8 5}}$ are all part of the customary international law. ${ }^{86}$ Consequently, they are applicable in all international armed conflicts. Although the 1949 Conventions are not considered customary international law, membership in them is almost as broad as the community of nations itself. ${ }^{87}$ Accepting the 1949 Conventions, like joining the United Nations, has become one of the de rigueur steps to evidence new nationhood. ${ }^{88}$

Not all parties to an international conflict are states, examples being the $\mathrm{Na}$ tional Liberation Front during the Vietnam conflict and the Palestine Liberation Organization in the Middle East conflicts. Only "Powers," that is, states, may become parties to the Conventions or, during a conflict, accept them and apply their provisions. ${ }^{89}$ If a party to the conflict is not a party to the 1949 Conventions and does not accept and apply them, there is no reciprocity, and the party to the conflict that is a member has no obligation to comply with the provisions of the Conventions in its relations with the nonmember. The Conventions would still govern relations between those parties to the conflict that are members or those that have accepted and applied their provisions.

85. 47 Stat. 2021 , T.S. No. 846.

86. ARmy Manual, supra note 48, at 4-7. Inclusion of the Hague Convention No. IV Respecting the Laws and Customs of War on Land and its annexed Regulations and the 1929 Geneva Prisoner of War Convention in customary international law was recognized in the Nuremberg judgments following World War II.

87. As of January 1, 1976, the United Nations had 143 members. The number of states that were parties to the First and Second Conventions was 143; to the Third and Fourth Conventions, 141 Dep'T of State, Treaties in Force 405, 410, 418,441 (1976).

88. The United Nations cannot accede to the 1949 Conventions because it is not a state, but in those conflicts to which it has been a party, it has announced that it would comply with the provisions of the Conventions. Taubenfeld, The Applicability of the Laws of War in Civil War. LAW and Civil. War in the Modern World 499, 513, 514-15 (J. N. Moore ed. 1974).

89. 1949 Conventions, supra notes $10,11,17$, at art. 2 . In noninternational conflicts, the parties can, by special agreement, bring into force provisions of the 1949 Conventions beyond common article 3. Presumably the same special agreements could be reached in an international conflict between the parties that are subject to international law and any other party to the conflict. 


\section{Protection of Civilian Infrastructure in Noninternational Conflicts}

\section{A. Applicable Law}

Nations are slow to accept customary international law as binding upon what they deem to be internal conflicts. Discretion or force of circumstances rather than recognition of a binding legal obligation has been influential in the few occasions in which the customary international law of war was applied in a noninternational conflict: "The application of the laws and usages of war to wars of insurrection or rebellion, is always undefined, and depends upon relaxations of the municipal law, suggested by humanity or necessitated by the numbers engaged in the insurrection."90 The customary international law of war became obligatory in these noninternational conflicts only upon recognition of belligerency by the constitutional government or by other states. ${ }^{91}$ Though this standard is reasonable for deciding when rights and duties with respect to neutral states appear, ${ }^{92}$ waiting for that political event should not

90. F. Lieber, Guerrilla Parties Considered with reference to the Laws and Usages OF WAR 21 (NeW York 1862).

91. Army Manual, supra note 48, at 9; M. Greenspan, The Modern Law of Land WarFARE 18-20 (1959). Of course, not all commentators have agreed with this proposition. Lauterpacht argued that once hostilities have become sufficiently vigorous that the conflict is indistinguishable from war, the law of war is applicable. H. LAUTERPACHT, RECOGNITION IN INTERNATIONAL LAw 245 (1947). There is some support for Greenspan's view from the American Civil War and before. See Dr. Lieber's statement at text accompanying note 90 supra. Dr. Lieber divided internal conflicts into three categories-insurrection, rebellion, and civil war-largely dependent on the extent of the conflict. Lieber Code, supra note 9, at arts. 149-151, reprinted in 1 THE LAW OF WAR, supra note 2, at 184. The latter two categories apparently could be of such a size as to "necessitate" the application of the laws and usages of war. This certainly appears to have been the view of the U.S. Supreme Court during the American Civil War (which would support Lauterpacht's position).

We must be governed by the principle of public law, so often announced from this Bench as applicable alike to civil and international wars, that all the people of each State or district in insurrection against the United States, must be regarded as enemies, until by action of the Legislature and the Executive, or otherwise, that relation is thoroughly and permanently changed.

Mrs. Alexander's Cotton, 69 U.S. 915, 920, 2 Wall. 404, 419 (1864).

"A civil war," says Vattel, "breaks the bands of society and government, or at least suspends their force and effect; it produces in the nation two independent parties, who consider each other as enemies, and acknowledge no common judge. Those two parties, therefore, must, necessarily, be considered as constituting, at least for a time, two separate bodies, two distinct societies. Having no common superior to judge between them, they stand in precisely the same predicament as two nations who engage in a contest and have recourse to arms.

This being the case, it is very evident that the common laws of the war-those maxims of humanity, moderation and honor-ought to be observed by both parties in every civil war. Should the sovereign conceive he has a right to hang up his prisoners as rebels, the opposite party will make reprisals, \&c., \&cc; the war will become cruel, horrible, and every day more destructive to the nation.

The Prize Cases, 67 U.S. 459, 476, 2 Black 635, 667 (1862).

92. A summary of these rights and duties appears at C. Fenwick, International Law 166 (4th ed. 1965). 
delay application of the rules from the laws of war designed for the protection of civilians.

International law is formed by consensus. States have rarely been willing to bind themselves to the same standards of conduct in their internal affairs that they found mutually advantageous in their relations with other states. Article 2 common to the 1949 Conventions provides for their application in cases of "armed conflict which may arise between two or more of the High Contracting Parties," and "to all cases of partial or total occupation of the territory of a High Contracting Party." The Hague Convention No. IV Respecting the Laws and Customs of War on Land specifically provides that "[ $\mathrm{t}]$ he provisions contained . . . in the present Convention, do not apply except between Contracting Powers."93

Since World War II international attention and concern for human rights in both international and noninternational conflicts has increased. Article 3 common to the 1949 Conventions requires each party to a conflict "not of an international character" to treat humanely all persons "taking no active part in the hostilities." To that end, it lists various coercive acts, which are prohibited "at any time and in any place whatsoever" with regard to such persons. ${ }^{94}$ The

93. Hague Convention No. IV, supra note 55, at art. 2. Of course, the provisions of this Convention and its annexed regulations are now considered customary international law. See note 86 supra.

94. 1949 Conventions, supra notes $10,11,17$, at art. 3. The complete text of the article is as follows:

In the case of armed conflict not of an international character occurring in the territory of one of the High Contracting Parties, each Party to the conflict shall be bound to apply, as a minimum, the following provisions:

(1) Persons taking no active part in the hostilities, including members of armed forces who have laid down their arms and those placed hors de combat by sickness, wounds, detention, or any other cause, shall in all circumstances be treated humanely, without any adverse distinction founded on race, colour, religion or faith, sex, birth or wealth, or any other similar criteria.

To this end, the following acts are and shall remain prohibited at any time and in any place whatsoever with respect to the above-mentioned persons:

(a) violence to life and person, in particular murder of all kinds, mutilation, cruel treatment and torture;

(b) taking of hostages;

(c) outrages upon personal dignity, in particular humiliating and degrading treatment;

(d) the passing of sentences and the carrying out of executions without previous judgment pronounced by a regularly constituted court, affording all the judicial guarantees which are recognized as indispensable by civilized peoples.

(2) The wounded and sick shall be collected and cared for.

An impartial humanitarian body, such as the International Committee of the Red Cross, may offer its services to the Parties to the conflict.

The Parties to the conflict should further endeavour to bring into force, by means of special agreements, all or part of the other provisions of the Present Convention.

The application of the preceding provisions shall not affect the legal status of the Parties to the conflict. 
Genocide Convention makes criminal the commission of various acts "with intent to destroy, in whole or in part, a national, ethical, racial or religious group, as such."95 Under the International Covenant on Civil and Political Rights:

Each State Party ... undertakes to respect and ensure to all individuals within its territory and subject to its jurisdiction the rights recognized in the present Covenant, without distinction of any kind, such as race, colour, sex, language, religion, political or other opinion, national or social origin, property, birth or other status. ${ }^{96}$

No derogation from certain articles is permitted even "in time of public emergency which threatens the life of the nation and the existence of which is officially proclaimed." 97 The enumerated articles include prohibitions on arbitrarily depriving anyone of life, ${ }^{98}$ on torture or cruel, inhuman, or degrading treatment or punishment, ${ }^{99}$ and only slavery. ${ }^{100}$ Scholars have devoted increasing attention to the alleviation of unnecessary suffering in noninternational conflicts, including efforts to synthesize the developing law of human rights in time of peace with the concern for human rights in wartime. ${ }^{101}$

of the conventions, we need not consider further the Genocide Convention. It protects certain groups from deliberate destruction by limiting the objectives that may legitimately be sought by any actor subject to international law, but otherwise it has little impact on methods of combat and selection of targets. It does not protect individuals. We shall examine more closely the customary international law, as well as article 3 from the 1949 Conventions and the provisions of the Rights Covenant not subject to suspension.

95. The Genocide Convention, December 9, 1948, art. 2, 78 U.N.T.S. 277, 280 (No. 1021) (entered into force January 12, 1951; the United States is not a party).

In the present Convention, genocide means any of the following acts committed with intent to destroy, in whole or in part, a national, ethnical, racial or religious group, as such:

(a) Killing members of the group;

(b) Causing serious bodily or mental harm to members of the group;

(c) Deliberately inflicting on the group conditions of life calculated to bring about its physical destruction in whole or in part;

(d) Imposing measures intended to prevent births within the group;

Id.

(e) Forcibly transferring children of the group to another group.

96. International Covenant on Civil and Political Rights, December 19, 1966, art. 3, (entered into force March 23, 1976) 21 U.N. GAOR Supp. (No. 16) 49, U.N. Doc. A/6316, reprinted in 6 Int'L Legal. Materials 368, 369 [hereinafter cited as Rights Covenant].

97. Id. at art. 4 , para. 1 .

98. Id. at art. 6.

99. Id. at art. 7 .

100. Id. at art. 8 .

101. A very interesting work in this line of thought is J. BOND, Rules of RIOT: INTERNAL CONFLiCT AND THE LAW OF WAR (1974). 


\section{B. Customary International Law and the Protection of Civilians}

Recognition of belligerency-the traditional test to determine whether the customary international law of war would be applied to noninternational conflicts-disappeared from the world scene after the Spanish Civil War. After World War II, the alternative-obtaining recognition by a government that the conflict within its borders has reached such a level that all or part of the international law of war should apply-has been only slightly less rare than recognitions of belligerency. Consequently, the adequacy of customary international law to protect civilian infrastructures of either the government or the insurgents is seldom put to the test.

\section{Immunity from Targeting}

If tested, however, good faith application would grant some protection. Application of the combatant-noncombatant distinction ${ }^{102}$ to noninternational warfare could not but help save lives that otherwise would be unnecessarily lost. Substantively, assassinations of civil servants and members of insurgent infrastructures as well as others would be banned by article 23(b) of the Hague Regulations. ${ }^{103}$ Several other provisions of those regulations, now customary international law, should lessen general civilian suffering from military attack. The general principle of customary law so aptly phrased by Lieber, that "[u]nnecessary or revengeful destruction of life is not lawful,"104 is also applicable.

\section{Protection While in the Power of an Adversary}

The failure of customary international law adequately to protect civilians in the power of their enemy during the two World Wars provided a major impetus for the 1949 Conventions. Understanding that, we cannot expect to find in the customary law rules adequate to protect civilians in conflicts further complicated by assertions of betrayal of allegiance owed to one or more parties to the conflict. In these situations the customary law's prohibition on "unnecessary or revengeful destruction of life" would continue. Nevertheless, customary international law, besides noting the combatant-noncombatant distinction, has also divided the population of provinces in revolt into three additional categories: loyal citizens, disloyal citizens "known to sympathize with the rebellion without positively aiding it, and those who, without taking up arms, give positive aid and comfort to the rebellious enemy without being bodily

102. See text accompanying notes 56-58 supra.

103. Accord, Lieber Code, supra note 9, at art. 148, reprinted in 1 THE LAW OF WAR, supra note 2 , at 184

104. Id. at art. 68 . 
forced thereto."105 The military commander was permitted to protect the loyal citizen from the hardships of war while throwing the "burden of the war ... on the disloyal citizens ... subjecting them to a stricter police than the noncombatant enemies have to suffer in regular war."106 This could even be enforced by requiring of every disloyal citizen an oath of allegiance upon penalty of expulsion, transfer, imprisonment, or fine. ${ }^{107}$

Customary international law has permitted consideration of acts deemed to betray proper allegiance in apportioning the economic burden of warfare and in providing for the future security of the state. The criteria of relevancy and proportionality to some legitimate end, derived from the customary international law concept of military necessity, are evident even if there is a substantially lower degree of compulsion for the actions taken. While discrimination in who should bear the burden of war, based on past action, is permissible, revenge and retribution without the benefit of judicial process are not approved.

\section{Criminal Liability for Support of One Faction}

\section{a. In Territory Controlled by the Captor}

Customary international law would not limit the power of a state to impose criminal punishment on its own nationals who have supported an insurgent within its own territory. In an international conflict, the authority of an occupying force to substitute its regulations for the criminal and civil law in the territory it occupies is, under customary international law, founded on the control made possible by its physical presence ${ }^{108}$ and is limited by military necessity. ${ }^{109}$ Within its own territory, however, a sovereign whose ties of allegiance were purportedly violated by captured insurgents may exercise authority based upon both territorial jurisdiction and nationality. The customary law of war places no limits upon these bases for criminal punishment.

An insurgent movement would not be a subject of customary international law-at least not until a state of belligerency was attained. Once the belligerent status was achieved, the movement would still lack sovereignty and therefore could exercise only the authority available to any armed force in occupation of another's territory. ${ }^{110}$

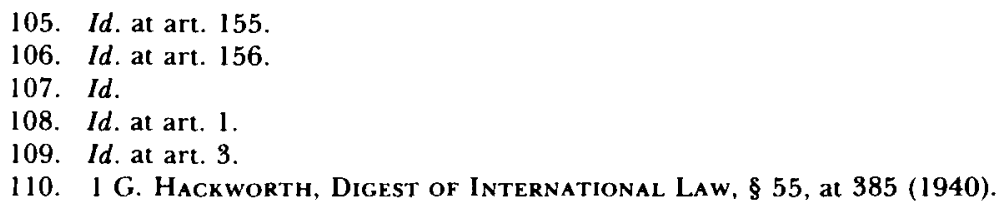




\section{b. In Other Territory}

The situation is more complicated when a civilian supports the party controlling the territory in which he finds himself and is subsequently captured by the adversary. Lieber's recognition that the commander will throw the burden of the war on the disloyal citizens ${ }^{111}$ contemplated the economic and political burden of the war. A different standard is appropriate when determining criminal punishment. If customary international law applicable in international conflicts were to be applied, the bulk of the civilian infrastructure would be subject to criminal punishment only for crimes that violated international law and not just the municipal law of the country; ${ }^{12}$ the military and political leaders of a rebellion, however, could still be tried for high treason. ${ }^{13}$

\section{Nonpunitive Restrictions on Movement}

Beyond the criteria of rationality and proportionality implicit in the principle of military necessity, customary international law would not limit the authority of an occupying force to restrict movement of the population within the territory it occupies. Lacking such restraints for international conflicts, the customary law of war cannot be expected to control restrictions on movement in noninternational conflicts.

\section{Status of Infrastructure Members}

To the extent that the customary international law of war protects civilians in noninternational conflicts, infrastructure members would generally share in that protection: they are noncombatants and not eligible targets. While criminally responsible for support given insurgents in territory controlled by the government, they should not, unless leaders of a rebellion, be similarly responsible for acts committed in territory controlled by the faction they support unless their acts violate the international law of war as well as municipal law.

Infrastructure members could be distinguished from other civilians when

111. Those sympathetic to the rebellion without positively aiding it who, without taking up arms, gave "positive aid and comfort . . . without being bodily forced thereto." Lieber Code, supra note 9, at art. 155, reprinted in 1 THE LAW OF WAR, supra note 2, at 185.

112. "[A]ll persons who are of particular and singular use and benefit to the hostile army or its government, are, if captured, on belligerent ground . . prisoners of war." Id. at art. 50. "A prisoner of war remains answerable for his crimes committed against the captor's army or people, committed before he was captured, and for which he has not been punished by his own authorities." Id. at art. 59. "A prisoner of war is subject to no punishment for being a public enemy." Id. at art. 56. This was apparently Lieber's understanding when he excepted those disloyal citizens who take up arms from his discussion on bearing the burden of the war.

113. Id. at art. 154 . 
nonpunitive movement restrictions and the economic and political burdens of war are distributed. For example, if the infrastructure member is a person "of particular and singular use and benefit to the hostile army," after capture he could be held as a prisoner of war. ${ }^{114}$

\section{Parties Regulated}

Once a noninternational conflict has satisfied the customary law of war's threshold of belligerency, that law will regulate all parties to the conflict that are recognized as belligerents. In a multiple party conflict there may be some independent groups not recognized as belligerents. If so, their acts are to be judged by municipal criminal law rather than by the customary international law of war.

The doctrine of reprisal in customary international law of war permits one party to a conflict to commit an otherwise illegal act that is in response to, and proportionate to, a previous illegal act by its adversary. The doctrine is cast in tit-for-tat phrasing, as if any illegal act would be an isolated incident subjected to quick retaliation, which would then pass into history as the conflict continues in a lawful manner toward its ultimate conclusion. It is designed to permit enforcement of the law of war rather than abandonment of it by one party claiming lack of compliance by the adversary. Unlike the Fourth Convention, the customary law of war does not prohibit reprisals against protected civilians. Even more serious, however, are those cases in which it is impossible to separate charge from countercharge, reprisal from atrocity. ${ }^{115}$ The vengeful acts then escalate as if the parties were totally unregulated by the law of war.

\section{1949 Conventions, Common Article 3}

\section{Onset of Application}

Article 3 common to the 1949 Conventions applies some basic principles of the 1949 Conventions to any "armed conflict not of an international character occurring in the territory of one of the High Contracting Parties." Unfortunately, the Conventions provide no guidelines for determining when an internal disturbance rises to the level of an armed conflict. Several variations on the traditional criteria for recognition of belligerency were advanced at the Diplomatic Conference in 1949 to define when article 3 would become applicable. ${ }^{116}$ None were adopted, however, and Pictet concluded that application of article 3 should not be limited to the conditions set forth in any of the proposals but should be applied as widely as possible. Pictet argues that the pro-

114. Id. at art. 50.

115. This was an important factor in aerial bombardment of cities during World War II. AIR Force Manual, supra note 48, at 5-4-5-6.

116. Pictet, IV Commentary, supta note 14, at 35-36. 
tections article 3 affords to noncombatants and to those rendered hors de combat are so minimal that each state must already grant them to common criminals; therefore, they should be granted to insurgents as well. ${ }^{117}$ These arguments were not persuasive at the 1949 Conference, and they have been no more persuasive in the years since.

Governments, by tradition and inclination, regard rebels and traitors as worse offenders than ordinary criminals. . . [even though] the soldier or civilian wounded or captured in a civil war is no less in need of care and decent treatment than the soldier wounded or captured in repelling an invader of his country. ${ }^{118}$

Governments seldom admit that article 3 is applicable to a conflict within their own borders ${ }^{19}$ even when the traditional requirements for a belligerency exist. Asking where banditry or terrorism in the hills stops and internal conflict requiring application of article 3 begins, Professor Baxter proposed a transition when the two contending factions, one of which is the government, are fighting it out, the motive is public good rather than private gain, and each is in command of some territory. ${ }^{120}$ Certainly some criteria besides the selfinterested assertion of the insurgents or bandits that they are operating in the public good are necessary to distinguish armed conflicts from criminal raids and riots. Yet some significant insurgencies have never controlled territory. When Palestine was a British mandate, the fighting there after World War II was aimed not at seizing ever larger bits of territory until Great Britain was forced into the sea but at attacking British prestige with the object of shaming her out. ${ }^{121}$ The IRA in Northern Ireland also appears interested not in seizing territory but in eroding British will to remain.

\section{Scope of Protection}

Subparagraph 1 of common article 3 proclaims a basic requirement of humane treatment for the people it protects. To that end subparagraphs (a)-(d) list various acts that are absolutely prohibited. From the language of article 3

117. Id. at 36. However, despite his rejection of the conditions contained in the various proposals advanced at the Conference, Pictet recognizes the value of "distinguishing a genuine armed conflict from a mere act of banditry or an unorganized and short-lived insurrection." Id. His conclusion is as follows:

Speaking generally, it must be recognized that the conflicts referred to in Article 3 are armed conflicts, with armed forces on either side engaged in hostilities-conflicts, in short, which are in many respects similar to an international war, but take place within the confines of a single country. In many cases, each of the Parties is in possession of a Id. portion of the national territory, and there is often some sort of front.

118. G. DRAPER, supra note 70, at 14 .

119. Id. at 15 n.47.

120. When Battle Rages, supra note 71 , at 74 .

121. M. BEGIN, supra note 35, at 52-53. 
it is unclear whether this list is exhaustive or merely illustrative. Pictet concludes that the listed prohibitions are absolute, with no "possible loophole ... no excuse, no attenuating circumstances," but that other acts may also violate the requirement for humane treatment, depending on the circumstances. ${ }^{122}$ We shall explore the requirement for humane treatment further when discussing nonpunitive restrictions on movement.

\section{Immunity from Targeting}

Some writers, rejecting Pictet's contention that article 3 requires no more than the minimal protections afforded any convicted felon, have advanced powerful and attractive arguments that article 3 incorporates some of the international rules for the protection of noncombatants for application in noninternational conflicts. ${ }^{123}$ There is, however, little from the records of the Diplomatic Conference of 1949 , as summarized in the Commentary on the Conventions, to support a conclusion that this was the intent of the drafters. Indeed, the contrary is true. The first three Conventions concentrate on relief for the victims of war-the wounded, sick, shipwrecked, and prisoners of war-evidencing little concern for the actual conduct of hostilities by combatant forces except where it might impinge directly upon the protected victims. Examples of the latter are the special protections afforded hospitals, hospital ships, medical transports, and medical personnel. Pictet emphasizes with respect to the Fourth Convention:

[T] he main object of the Convention is to protect a strictly defined category of civilians from arbitrary action on the part of the enemy, and not from the dangers due to the military operations themselves. Anything tending to provide such protection was systematically removed from the Convention.

It may be wondered, nevertheless, whether the wording of the title, even now as it has been amended, really reflects the precise purpose of the Convention, which, it must be repeated, is above all concerned with the protection of civilians against arbitrary action by the enemy, and not against the whole series of dangers which threaten them in wartime. ${ }^{124}$

Article 3 had its origin in an ICRC draft proposing that the principles of the Conventions must be applied by the adversaries in noninternational conflicts. ${ }^{125}$ Faced with extensive opposition to application of so much of the Conventions to noninternational conflicts, agreement was reached on article 3 , regarded as more limited in its scope. ${ }^{126}$ Considering that the Conference fo-

122. Pictet, IV CommentaRy, supra note 14 , at 38.

123. J. Bond, supra note 101, at 80-136. See also Farer, Humanitarian Law and Armed Conflicts: Toward the Definition of "International Armed Conflict," 71 Colum. L. Rev. 37, 40 (1971).

124. Pictet, IV Commentary, supra note 14, at 10-11. The title referred to is the Fourth Convention's. The change was from "for the Protection" to "Relative to the Protection."

125. Id. at 30 .

126. Id. at $32-34$. 
cused on relief for the victims of war and civilians before they became victims $^{127}$ rather than on the rules regulating military operations by combatant forces, and that article 3 was accepted as a version more limited than the original draft, which proposed application of the principles of the Conventions, it could not have been the drafters' intent for article 3 to adopt the rules regulating combat and apply them to noninternational conflicts. ${ }^{128}$

Concluding that the requirement for humane treatment in article 3 was not intended to extend beyond the bounds of the 1949 Conventions to pick up the Hague Regulations does not answer the question of how far the requirement for humane treatment does extend. For that matter, we may also ask how far the listed prohibitions may be stretched. For example, the prohibition of violence to life and person cannot intend to preclude all violence felt by protected persons. Even under the law applicable in international conflicts, incidental damage to civilians is permitted. The violence prohibited is perhaps inferable from one of the examples given-murder, which involves not just the application of violence resulting in death but a deliberate use of unjustified and inexcusable (and therefore illegal) violence resulting in death. This element of deliberate intent in the illegal use of violence is found also in the other examples given: mutilation, cruel treatment, and torture.

For standards to measure whether violence is unjustified and inexcusable, we can only look to the correlative principles that form the foundation for the law of war: military necessity and humanity. Article 3 shares a common goal with them-to minimize the unnecessary destruction of human values, in this case by protecting those uninvolved or left helpless by the conflict. This conclusion is also supported by Pictet's findings in his Commentary on the Fourth Convention: "[T]he main object of the Convention is to protect a strictly defined category of civilians from arbitrary action on the part of the enemy." 129 “[H]umane treatment . . . is incompatible with. . . . any act of violence or intimidation inspired not by military requirements or a legitimate desire for security, but by a systematic scorn for human values (insults, exposing people to public curiosity, etc.)."130

A crucial distinction exists, however, between the operation of military necessity in article 3 and military necessity in the law applicable in international conflicts. We earlier found two components in military necessity: a compelling

127. Id. at 5 .

128. Through practice, theoretically, agreements as fundamental to the law of war as the 1949 Conventions could, like a constitution, be infused with new substance beyond the drafter's original conception. It is evident, however, that nations have not so chosen to expand the scope of article 3 .

129. Pictet, IV Commentary, supra note 14 , at 10 (discussion of title of the Fourth Convention).

130. Id. at 204 (discussion of requirement for humane treatment under article 27 of the Fourth Convention). 
requirement for the military action taken if legitimate military objectives are to be achieved, and subjection of the compelling requirement to more specific rules of the law of war whenever there was a conflict between the two. The force motivated by the compelling requirement also had to satisfy the tests of relevancy and proportionality.

Article 3 suffers in comparison. While it requires some relationship between the use of force and legitimate military objectives-otherwise the use of force would be arbitrary-there does not appear to be the same compelling or imperative nature to that relationship. Except for the very sparse list of specific prohibitions, the detailed rules to which the compelling requirement is always subject in international conflicts are missing from article 3 . The list of prohibitions generally contemplates actions occurring after an individual is captured rather than earlier during actual combat. The customary prohibition on targeting of civilians is missing except insofar as a particular civilian may fall within the specifically defined class at the beginning of article 3 .

\section{Forfeiture of Protection}

Article 3 protects only those "taking no active part in the hostilities." Earlier we found that in international conflicts civilians are allowed to support their own armed forces without forfeiting their immunity from direct attack so long as their assistance does not cause direct damage to the enemy forces or military property and does not betray some special mission entrusted or required of them by the enemy forces. ${ }^{131}$ For these prohibited acts, civilians will also forfeit protection under article 3 while the activity continues. In international conflicts the civilian bureaucrat and insurgent administrator are protected from direct attack because their activity does not fall within the scope of the proscribed hostile acts. Their position is less clear under article 3.

The definitions of "taking part," "actively," and "hostilities" were not decided at the 1949 Diplomatic Conference. ${ }^{132}$ Nor is the subject discussed in Pictet's commentaries on the 1949 Conventions. The ban on active participation may encompass no more than the acts that forfeit immunity under international law. Yet if in 1949 the intention had been to adopt existing international law on this subject, it would have been much clearer to refer expressly to acts prohibited of noncombatants under international law rather than to adopt a new formulation. ${ }^{133}$ Since the negotiating history of article 3 generally displayed a reluctance by nations to be bound in internal conflicts by interna-

131. See text accompanying notes 75-77 supra.

132. ICRC, Document No. CE/3b, Protection of the civilian population against dangers of hostilities 22 (January, 1971) (document submitted to the Conference of Government Experts on the Reaffirmation and Development of International Humanitarian Law Applicable in Armed Conflicts (CDDH), 1971) [hereinafter cited as ICRC, Civilian Protection Document].

133. Of course, reference to participation is not totally new. The similar phrase, "active part in the war," was used by Von Martens. G. von MARTENs, supra note 7. 
tional law, we cannot conclude that the international law rule was adopted here without positive evidence of such an intention.

A broad definition of active participation would include any who by their acts or words support one faction or another in the internal conflict even though they wreak no violence on the side they disfavor. Such a definition would certainly include our civilian infrastructure on both sides of the conflict. ${ }^{134}$ There is no certain interpretation of article 3 . Those concerned with

134. Precedent for a broader definition can be found in the decisions of the Mixed Claims Commission following World War I. At issue was whether the individuals submitting claims for damages suffered due to German military action were members of the "civilian population" of the United States and, at the time of the injury or damage, "civilian" as those terms were used in article 232 and annex I to section I of part VIII of the Treaty of Versailles. Treaty of Versailles, June 28, 1919. [1919] Gr. Brit. T.S. No. 4 (Cmd. 153), 11 Martens Nouveau Recueil, ser. 3, at 323-677. In the leading Damson Case (U.S. v. Germany), the claimant was master of an oil tanker requisitioned by the United States Shipping Board and operated by the War Department as a public ship. The ship was sunk by a German submarine while transporting oil from the United States to Europe for United States military forces. Damson claimed damages under the Treaty for personal injuries and loss of personal property. Umpire Parker decided that Damson's civilian status under the laws of the United States was irrelevant, applied a test of the "object and purpose" of his pursuits and activities at the time of the injury or damage complained of, and decided that if his activities "were at the time aimed at the direct furtherance of a military operation against Germany or her allies," then he could not be held to be a "civilian" or part of the "civilian population" within the meaning of the Treaty. Pointing to Damson's employ and control by the United States, that he was subject to military discipline and that his mission was "directly in furtherance of a military operation against Germany or her allies," the Umpire held Damson was not a "civilian" at the time of the damage and injury. Damson Case (U.S. v . Germany), 7 R. INT'L A RB. AwARDS 184, 197-98 (1925).

Umpire Parker emphasized the "object and purpose" test with a further illuminating example. The taxicabs of Paris were requisitioned by the Military Governor of Paris and were used to transport French reserves to meet and repel the oncoming German army. While so engaged, the taxicabs were regarded as military matériel. While driving them on these missions, their drivers also were not part of the "civilian population" since the "civilian population" is not generally exposed to such risks. It mattered not that the drivers had not been enrolled in the army, were not authorized to wear uniforms or bear arms, and did not possess a "military status." Id. at 198.

This principle was extended in the Hungerford Case. There a group of men recruited by the YMCA for service with the American Expeditionary Forces in Europe lost their personal belongings when the British merchant ship on which they were sailing was sunk by a German submarine. Applying the Damson "object and purpose" test, Umpire Parker found that Hungerford and the other YMCA men were "engaged in activities aimed at the direct furtherance of military operations against Germany or her allies," and therefore could not be "civilians" under the Treaty. The YMCA entertainment organization was recognized as indispensable to the social welfare of the Army, the organization had the specific military function of maintaining and promoting morale, and the men were subject to courtmartial for any offenses committed while accompanying or serving with the armies in the field. That they were not formally inducted into the Army and were not in the pay of the United States Government was immaterial. The "civilian population" was limited to "passive victims of warfare, not to those who entered the war zone, subjected themselves to risks to which members of the civilian population generally were immune, and participated in military activities, whether as combatants or noncombatants." The Hungerford Case (U.S. v. Germany), 7 R. InT'L. Arb. Awaros 368, 370-71 (1926).

Certainly denial of civilian status for claims purposes is a far different matter than denial of civilian status for purposes of protection from the effects of hostilities. Yet the construction of "direct furtherance of military operations" as including the transport of oil to military forces, the transport of troops by taxicab, and the provision of entertainment for morale purposes does raise questions about our civil servants and their insurgent administrative counterparts. Denial of com- 
protecting humanitarian values in conflict will tend toward the narrower international definition of active participation, while the commander in the field may tend toward the broader view, which affords him more latitude in choice of targets and selection of means. The Conference did not say who was right.

\section{Protection While in the Power of an Adversary}

After capture article 3 grants no one immunity from criminal prosecution for his past acts, ${ }^{135}$ but protected persons, including members of armed forces who wreaked death and destruction before being captured, surrendering, or falling hors de combat, cannot suffer sentence or execution "without previous judgment pronounced by a regularly constituted court affording all the judicial guarantees which are recognized as indispensable by civilized peoples." ${ }^{136}$ This trial requirement was intended to reduce the number of innocent victims too often subjected to summary justice. ${ }^{137}$ There appears no basis to deprive the noncombatant civil servant or infrastructure members of this protection. Whether or not his precapture activity is deemed active participation in hostilities, it obviously terminates upon his capture. The characterization of his former activity as criminal, however, will depend on applicable municipal law, not on international law.

\section{Nonpunitive Restrictions on Movement}

Article 3 does not address the problem of nonpunitive restrictions on movement directly, since nonpunitive restrictions on movement are not included in the list of absolute prohibitions. Instead, each particular case must be examined to see if the conditions of the restriction imposed are so severe as to violate one of the specific prohibitions contained in subparagraphs 1(a)-(d) or the general requirement for humane treatment. Conditions so severe as to violate a listed prohibition should be obvious; however, the general requirement of humane treatment merits further discussion.

Article 3 contains no discussion of the requirement for humane treatment beyond the prohibition of adverse distinction on enumerated grounds and the listed prohibitions. A humane treatment requirement and additional examples of inconsistent acts are found elsewhere in the Fourth Convention-in articles $27,32,38,100$, and 127 . Under those articles humane treatment requires the individual to be protected against acts or threats of violence, brutality, insults,

\footnotetext{
batant status, combined with denial of civilian status, would leave infrastructure members on both sides of the conflict in a very unenviable position. It was concern over the possibility of such a broad interpretation for the phrase "active part in the hostilities" from article 3 that led the ICRC to suggest the phrase, "directly participate in military operations," in an early draft of article 51 (3) of Protocol I. ICRC, Civilian Protection Document, supra note 132, at 21-28.

135. Pictet, IV CommentaRy, supra note 14, at 39.

136. Common article 3(1)(d) of the Geneva Conventions of 1949.

137. Pictet, IV Commentary, supra note 14, at 39.
} 
and public curiosity and requires that reasonable regard be paid to his physical and mental well-being. The problem is whether these standards set in articles concerning international conflicts may properly be used for interpreting article 3 concerning noninternational conflicts. Is the humane treatment requirement the same in all conflicts? ${ }^{138}$

Where applicable, articles 27 and 28 expressly preserve the authority of the party exercising power to take the measures of control and security necessary for the prosecution of the war, that is, to take the measures dictated by military necessity with its criteria of relevancy and proportionality. The legitimate objective of nonpunitive restrictions is the security of the armed forces and war effort of the party imposing the restrictions. So long as that security is the guideline for determining the severity of the restrictions imposed, it should be possible to formulate conditions of restriction that preserve this security without committing the sins of omission or commission addressed in the articles cited.

A similar result is obtained when applying a military necessity analysis to such restrictions in noninternational conflicts regulated by article 3 . Certainly security and control of certain individuals will be as necessary for the success of the party to a noninternational conflict as for the party to an international conflict. Article 3 cannot prohibit these security measures. But when the severity of the conditions imposed is increased to achieve other objectives as well, then the nature of those objectives will determine whether the heightened restrictions violate article 3 . For example, conditions that seek retribution for past acts or deterrence of similar activity by others may violate article 3 , for these objectives are normally the subject of criminal punishment proceedings. Thus, the restrictions may be tantamount to passing a sentence without previous judgment of a regularly constituted court, in violation of article 3, paragraph $1(\mathrm{~d})$. In such an analysis, the standards set for humane treatment by other articles do not dictate the interpretation of article 3 , but they do provide examples of acts not justified by military necessity.

\section{Status of Infrastructure Members}

Article 3 contains no language that refers directly to members of the civilian infrastructure of each party to the conflict, but the members can be accorded treatment different from that given the general population. We considered the risk that the actions of infrastructure members may be considered active participation in the hostilities, thus forfeiting protection under article 3 until after capture by their enemy. Even if not criminally prosecuted, former infrastructure members could probably expect nonpunitive restrictions on their movements.

138. Pictet refers directly and unquestioningly to article 27 of the Fourth Convention for the meaning of "humane treatment." $I d$. at 38. 
Perhaps the most serious threat facing captured infrastructure members, however, is adverse distinction. In article 3, paragraph l's requirement for humane treatment without adverse distinction on enumerated grounds or "other similar criteria" does not protect them. Pictet specifically mentions political ideology as one of the factors commonly dividing belligerent parties in a noninternational conflict. ${ }^{139}$ Yet political ideology is not one of the criteria listed in article 3 as prohibited grounds for adverse distinction. This is a strange omission, since the list of prohibited criteria in article 3 is longer than the lists in articles 13 and 27-both of which include political opinion. It can probably be included, however, within article 3's "similar criteria."

Prior hostile activity or support of the capturing party's adversary, however, would not be included among the "similar criteria." Though prior noncombatant activity in support of the capturing party's enemy may permit adverse distinction, it cannot totally negate the requirement for humane treatment. Even combatants are entitled to humane treatment after laying down their arms or being placed hors de combat. The absolute prohibitions listed in subparagraphs (a)-(d) remain absolute even when activity prior to capture is considered.

\section{Parties Regulated}

A major innovation of article 3 is the expansion of application to all parties to a noninternational armed conflict, including those defying the authority of the established government, who presumably are not parties to the Conventions since they lack governmental status. As the legal representative of a contracting party to the Conventions, the established government is bound by article 3. Any rival authority claiming or seeking to represent the state internationally must first succeed in its quest and then follow the procedures for denunciation set forth in each of the Conventions ${ }^{140}$ before it can escape the international obligation assumed by its predecessor. ${ }^{141}$ Failure of an insurgent movement to comply with the minimal standards required by article $\mathbf{3}$ would

139. J. Pictet, Commentary, I Geneva Convention for the Amelioration of the Condtion of the Wounded and Sick in Armed Forces in the Field 55 (1952) [hereinafter cited as Pictet, I Commentary].

140. A high contracting party may denounce any or all of the Conventions, the denunciation to take effect one year after written notification has been made to the Swiss Federal Council. Additionally, there are further safeguards delaying the date at which denunciation takes effect when the denouncing power is involved in, or has recently been involved in, a conflict. First Convention, supra note 17, at art. 63; Second Convention, supra note 17, at art. 62; Third Convention, supra note 10, at art. 142; Fourth Convention, supra note 11 , at art. 158.

141. This is the theory advanced by Pictet. Pictet, IV Commentary, supra note 14, at 37. This and other theories to justify requiring insurgents to apply article 3 are listed and capably analyzed at Note, The Geneva Convention and the Treatment of Prisoners of War in Vietnam, 80 HaRv. L. Rev. 851 (1967), reprinted in 2 The VIETNAM WAR AND INTERnational. LAW, supra note 46, at 398, 403-405 (1969). 
identify them as nothing more than brigands or anarchists, according to Pictet. ${ }^{142}$

Because of the reluctance of governments to admit that an internal disturbance rises to the level of an armed conflict requiring application of article $3,{ }^{143}$ this optimistic analysis and exhortation of Pictet has seldom been tested. It is noteworthy, however, that during the Vietnam conflict, the National Liberation Front announced they were not bound by the Geneva Conventions since they had not signed them. ${ }^{144}$

An undoubted advantage of article 3 is that reciprocity is not a condition for its application. The 1949 Diplomatic Conference deleted a clause providing for application on a reciprocal basis, leaving the clear implication that failure of one party to comply with the standards of article 3 does not release other parties to the conflict from their obligations. ${ }^{145}$

\section{International Covenant on Civil and Political Rights}

\section{Immunity from Targeting}

The Rights Covenant's bans on arbitrary deprivation of life and cruel and inhuman treatment are among the articles from which no derogation is permitted even "in time of public emergency which threatens the life of the nation and the existence of which is officially proclaimed."146 Unlike article 3 of the 1949 Conventions, the Rights Covenant has no threshold problem since its application begins in peacetime. Determining the substantive content hidden within these brief phrases, however, is difficult.

Certainly, deliberate destruction of life unrelated to or disproportionate to military objectives is prohibited. Like article 3 of the 1949 Conventions, the Rights Covenant appears to include at least a modicum of the principle of military necessity. But there is even less reason to believe these phrases incorporate the more detailed provisions of the international law of war than to believe article 3 does. The provisions of the Rights Covenant are much more concerned with treatment of individuals physically in the power of their government than with regulating combat between the government's armed forces and its armed adversaries.

142. Pictet, IV Commentary, supra note 14, at 37.

143. See text accompanying notes 116-121 supra.

144. 5 Int'l Rev. Of THe Red Cross 636 (1965), cited in Levie, Maltreatment of Prisoners of War in Vietnam, 2 The Vietnam WAR AND INTERnATIONAL LAw, supra note 46, at 361, 362 (1969). The National Liberation Front did affirm, however, that its prisoners were humanely treated and that it collected and cared for enemy wounded. Id.

145. Pictet, IV Commentary, supra note 14, at 37.

146. Rights Covenant, supra note 96 , at art. 4(1). 


\section{Protection While in the Power of the Government}

The ban on arbitrary deprivation of life must require a judicial proceeding with at least minimal guarantees of due process before a death sentence may be levied and executed on anyone in governmental hands. As under article 3, the ban on inhuman treatment would prohibit any systematic scorn for human values.

\section{Restrictions on Movement}

Article 9, which protects against arbitrary arrest and detention and deprivation of liberty except on grounds and by procedures established by law, is subject to derogation during public emergencies. The existence of Article 9, however, argues against interpreting article 7's nonderogable ban on cruel or inhuman treatment as limiting any but the most severe restrictions on movement under the most egregious circumstances. Thus, the Rights Covenant offers little protection during serious civil strife against either punitive or nonpunitive restrictions on movement.

\section{Status of Infrastructure Members}

Each State Party to the present Covenant undertakes to respect and to ensure to all individuals within its territory and subject to its jurisdiction the rights recognized in the present Covenant, without distinction of any kind, such as race, colour, sex, language, religion, political or other opinion, national or social origin, property, birth or other status. ${ }^{147}$

The rights recognized in the Covenant do not prohibit the government from imposing very severe criminal punishments on those who support a rebellion. The members of the insurgent infrastructure, though not subject to adverse distinction because they share a suspect political opinion, race, or language, can still be punished for the acts they have committed.

\section{Parties Regulated}

Only the government has obligations under the Rights Covenant. ${ }^{148}$ Failure to bind other parties to a noninternational conflict means the government cannot claim lack of reciprocity or breach to release it from its obligation; it has already accepted the obligation with full knowledge of its unilateral character. But since the obligation is unilateral, there is additional incentive for

147. Rights Covenant, supra note 96, at art. 2(1).

148. The fifth paragraph of the Preamble recognizes "that the individual, having duties to other individuals and to the community to which he belongs, is under a responsibility to strive for the promotion and observance of the rights recognized in the present Covenant." No obligations are imposed upon individuals by articles of the Rights Covenant, however. An optional protocol would permit a State Party to recognize the competence of the Human Rights Committee (set up in Part IV of the Rights Covenant) "to receive and consider communications from individuals subject to its jurisdiction who claim to be victims of a violation by that State Party of any of the rights set forth in the Covenant." Rights Covenant, supra note 96, at Optional Protocol, art. 1. 
the government to interpret it as narrowly as possible, especially if the practice of its adversary is inconsistent with the terms of the Covenant.

IV

Protocol I ANd the Civilian Infrastructure

\section{A. Protection Against Targeting}

\section{Protected Group}

Under Protocol I civilians are defined by exclusion--those not included within the combatant categories of prisoners of war in article 4, paragraphs $A(1)-A(3)$ and $A(6)$, of the Third Convention and article 43 of Protocol I. ${ }^{149}$ If an organizational distinction is maintained between the armed forces and the administrative infrastructure of a party to a conflict, the members of the administrative infrastructure are civilians for the purposes of Protocol I whether the party to the conflict is an insurgent movement or a government.

\section{Forfeiture of Protection}

Civilians benefit from Protocol I's articles 48-67, entitled "General Protection against Effects of Hostilities," "unless and for such time as they take a direct part in hostilities."150 This rule strongly resembles the hostile-acts doctrine of customary international law, but here the use of different terminology and the failure to refer to existing law raises the possibility that a different substance is intended; this could have serious implications for civilians who are infrastructure members.

\section{Status of Infrastructure Members}

A broad definition of "hostilities" in Protocol I could obviously draw in our civilian infrastructure members as direct participants, thereby forfeiting their protection from the effects of hostilities. Three factors militate against considering infrastructure activity as direct participation in hostilities; these indicate an intent of the drafters to incorporate the traditional international law doctrine of hostile acts in this language.

First, the content of articles 48-67 indicates that "hostilities" in the title of those articles is synonymous with the conduct of military operations. The basic rule set forth in article 48 protects the civilian population from military operations. The same phrase, "military operations," is used in the other articles as well, ${ }^{151}$ except when the still more restrictive term "attack" is used. Article 49(1) defines attack as "acts of violence committed against an adversary,

149. ICRC, Protocol I, supra note 18, at art. 50(1).

150. Id. at art. 51(3).

151. Rights Covenant, supra note 96 , at arts. 51, 57, 58, 59, 60. 
whether in defence or offence." The substance of articles 48-67 indicates that the "hostilities" from whose effects civilians are to be protected are military operations against specific objectives. Only direct participation by a civilian in such military operations should forfeit this protection.

Second, the travaux préparatoires support a narrow interpretation for "hostilities" as it is used in article 51(3). In 1971 the ICRC suggested the use of the term "military operations" since "hostilities" was thought to have "too broad a meaning, covering a whole series of acts and circumstances in which civilians are directly involved."152 The Conference of Experts chose "hostilities" for their 1972 draft, but they were apparently rejecting only the ICRC's fear that "hostilities" would be interpreted too broadly. The commentary on the 1972 draft listed the criterion for "direct participation in hostilities" as "military or combatant activity." 153 During the second (1975) session of the Diplomatic Conference, several delegations expressed their understanding that "hostilities" in the predecessor of article 51(3) included "preparations for combat and return from combat." 154 Such an expression for the record would be totally unnecessary unless a very narrow definition of "hostilities" were assumed.

Third, the recognition in article $43(2)$ of the combatants' right "to participate directly in hostilities" again ties "hostilities" to military operations. Since combatants are defined in that same paragraph as members of the armed forces of a party to the conflict, direct participation in hostilities must refer to the acts directly causing damage or injury to the enemy, which, under international law, are prohibited to all persons but lawful combatants. It is concluded, therefore, that members of a civilian infrastructure distinguished from the armed forces of a party to a conflict are entitled to protection from the effects of hostilities on the same basis as other civilians.

\section{Parties Regulated}

All parties to a CAR conflict will be bound by Protocol I if their state is a party to the Protocol. Like article 3 of the 1949 Conventions, Protocol I will be considered binding upon all parties to a CAR conflict even if only the government concerned, or its predecessor, signed and ratified the Protocol. Also like article 3 , not who is bound, but when, is the problem.

152. ICRC, Civilian Protection Document, supra note 132, at 27.

153. ICRC, 2 Commentary 84 (January, 1972) (pt. 1) (submitted to the Conference of Government Experts on the Reaffirmation and Development of International Humanitarian Law Applicable in Armed Conflicts, May 3-June 3, 1972).

154. 15 ICRC, Official Records of the Diplomatic Conference on the Reaffirmation and Development of International. Humanitarian Law Applicable in Armed Conflicts, GeNEVA (1974-1977) 327, 330 (Report to Committee III on the Work of the Working Group, February 24, 1975) (CDDH/III/224) [hereinafter cited as ICRC, CDDH Official Records]. 
The Protocol applies from the beginning of the armed conflict, ${ }^{155}$ but this requirement merely perpetuates the threshold problem posed by article 3 of the 1949 Conventions: When does an internal disturbance rise to the level of an armed conflict? This was not a problem in Protocol I until article 1 was amended to include CAR conflicts among the situations to which the Protocol applies. Protocol II, which concerns noninternational armed conflicts, deals with this question:

1. This Protocol, which develops and supplements Article 3 common to the Geneva Conventions of 12 August 1949 without modifying its existing conditions of application, shall apply to all armed conflicts which are not covered by Article I of ... [Protocol I] and which take place in the territory of a High Contracting Party between its armed forces and dissident armed forces or other organized armed groups which, under responsible command, exercise such control over a part of its territory as to enable them to carry out sustained and concerted military operations and to implement this Protocol.

2. This Protocol shall not apply to situations of internal disturbances and tensions, such as riots, isolated and sporadic acts of violence and other acts of a similar nature, as not being armed conflicts. ${ }^{156}$

No similar threshold for CAR conflicts is provided in Protocol I. ${ }^{157}$

\section{B. Protection While in the Power of the Enemy}

\section{Complemented Law}

Protection of a civilian after he is in the power of the opposing party is the subject of Protocol I's articles 72-79. The provisions of these articles "are additional to the rules concerning humanitarian protection of civilians and civilian objects in the power of a Party to the conflict contained in the Fourth Convention, particularly Parts I and III thereof, as well as to other applicable rules of international law relating to the protection of fundamental human rights during international armed conflict." ${ }^{158}$ Since articles $72-79$ are only supplemental in intent, we shall first ask which of the supplemented rules apply to CAR conflicts.

155. ICRC, Protocol I, supra note 18, at art. 3(a).

156. ICRC, Protocol II, supra note 19, at art. 1.

157. This failure adequately to define the threshold at which a disturbance may become a CAR conflict has been decried both by those critical of the inclusion of CAR conflicts within the scope of Protocol I-Graham, The 1974 Diplomatic Conference on the Law of War: A Victory for Political Causes and a Return to the "Just War" Concept of the Eleventh Century, 32 WASH. \& LEE L. REV. 25, 50 (1975) -and by those sympathetic to such an expansion of the coverage of law over armed conflicts-Bond, Amended Article I of Draft Protocol to the 1949 Geneva Conventions: The Coming of Age of the Guerrilla, 32 Wash. \& LeE L. Rev. 65, 69-74 (1975). Perhaps standards similar to those in Protocol II may be inferred from the nature of the international armed conflicts to which Protocol I assimilates CAR conflicts.

158. ICRC, Protocol I, supra note 18, at art. 72. 
The Fourth Convention applies during armed conflict between two or more high contracting parties and in "all cases of partial or total occupation of the territory of a High Contracting Party." 159 Some cases of alien occupation may satisfy this requirement if the parties to the conflict were high contracting parties prior to the occupation; this condition would not be satisfied in conflicts against colonial domination or racist regimes, since the peoples fighting such a conflict would not previously have been an independent state with the capacity of adhering to the 1949 Conventions. ${ }^{160}$ Thus, the Fourth Convention does not apply to many CAR conflicts if application is determined solely by the language of the Convention.

Article 1(3) of Protocol I applies the Protocol to "the situations referred to in Article 2 common" to the Geneva Conventions. Article 1(4) defines "the situations referred to in the preceding paragraph" to include CAR conflicts. From this language it is not clear whether the drafters intended only to ensure application of the Protocol to CAR conflicts or whether they entertained the more ambitious aim of amending the coverage of the 1949 Conventions. The former could have been more easily and clearly attained by adding a clause at the end of article 1(3) to ensure the application; the latter would be better achieved with language expressly conveying an intent to amend the scope of the earlier Conventions. The report of the United States delegation to the first (1974) session of the Diplomatic Conference indicates that supporters of the amendment to include CAR conflicts argued that CAR conflicts would be governed by the 1949 Conventions as well as by Protocol I. ${ }^{161}$ That the language chosen accomplished this purpose is doubtful for several reasons.

First, referral in article 1(4) of Protocol I to the "preceding paragraph" (1(3), concerned with application of Protocol I) rather than directly to article 2 of the 1949 Conventions weakens any assertion of intent to amend article 2 and the coverage of those Conventions. Second, if amendment of the coverage of the 1949 Conventions was desired, this could be better accomplished by amending the Conventions to permit "peoples" fighting CAR conflicts to accede to the Conventions. Third, if the present language did in fact make application of the 1949 Conventions to CAR conflicts obligatory, it would require an insurgent movement fighting in the conflict to comply with many provisions for the protection of war victims at a time when the movement might lack the resources to do so. Many insurgent movements would be

159. Fourth Convention, supra note 11 , at art. 2.

160. The Conventions are open to accession by "Powers" only. Id. at art. 59.

161. Report of the U.S. Delegation to the Diplomatic Conference on the Reaffirmation and Development of International Humanitarian Law Applicable in Armed Conflicts, Geneva, Switzerland, February 20-March 29, 1974, at 6-7 (1974) (prepared by Professor Baxter, a member of the U.S. delegation; submitted to the Secretary of State by Mr. George Aldrich, Chairman of the U.S. delegation). The United States opposed this amendment of article 1. 
unable to provide the fair and regular trial required by the Third and Fourth Conventions. Yet failure to do so is a "grave breach" of the Conventions. ${ }^{162}$ Each high contracting party is obligated to search for persons alleged to have committed such breaches and to try them before its own courts, or, alternatively, to hand them over to another high contracting party for trial. ${ }^{163}$ Nations so sympathetic to "peoples" fighting CAR conflicts could not have intended such a result.

Fourth, many of the provisions of the 1949 Conventions were drafted with such a complete focus on traditional international conflicts (particularly on World War II) that there is no possibility for detailed compliance in a conflict between an insurgent movement and its adversary government, though some of the basic principles could be fulfilled. ${ }^{164}$ For example, many of the provisions of the Fourth Convention deal with the obligations of an occupying power and the rights of the population in occupied territory. In conflicts involving colonial domination or racist regimes in which all inhabitants of the territory, oppressed and oppressors, share a common nationality, present legal concepts of occupation do not apply. ${ }^{165}$

At issue is the proper interpretation of a treaty when its text conflicts with the expressed intent of the drafters. The relative importance of text versus travaux preparatoires varies with the source consulted. ${ }^{166}$ But when one of the two competing interpretations would appear to give absurd results, that in itself merits considerable weight.

Articles 72-79 are additional not only to the Fourth Convention, but also

162. Third Convention, supra note 10, at art. 130; Fourth Convention, supra note 11, at art. 147.

163. Third Convention, supra note 10, at art. 129; Fourth Convention, supra note 11, at art. 146.

164. This is recognized even by commentators sympathetic to the amended article 1. E.g., Bond, supra note 157, at 71-73.

165. For example, the Army Manual provides, "Belligerent occupation in a foreign war, being based upon the possession of enemy territory, necessarily implies that the sovereignty of the occupied territory is not vested in the occupying power." ARMY MANUAL, supra note 48, at 138, para. 353. Whether either the government or the insurgent movement in a CAR conflict would ever admit that their control of a portion of the national territory constitutes occupation is extremely dubious.

166. Under the Vienna Convention on the Law of Treaties,

Recourse may be had to supplementary means of interpretation, including the preparatory work of the treaty and the circumstances of its conclusion, in order to confirm the meaning resulting from the application of Article 31, or to determine the meaning when the interpretation according to Article 31 :

(a) leaves the meaning ambiguous or obscure; or

(b) leads to a result which is manifestly absurd or unreasonable.

Vienna Convention on the Law of Treaties, May 23, 1969, art. 32, U.N. Doc. A/CONF. 39/1 1/Add. 2, 23 May 1969; 63 Aм. J. INT'L L. 875, 885 (1969). Since an absurd result is reached in this case only if the travaux preparatoires are consulted, the Vienna Convention weighs against its consideration. Other sources set no priorities among the factors to be considered. See, e.g., Restatement (Second) of The Foreign Relations Law of the United States $§ 147(2)$, at 452 (1965). 
to other international rules for the protection of fundamental human rights during international armed conflict. Locating these other applicable rules is a problem in itself; the first source is customary international law, including the 1907 Hague Regulations and the general principles of the 1929 Geneva Prisoner of War Convention. In the past the customary international law of war has not been applicable to noninternational conflicts, including CAR conflicts, until belligerency was recognized. States did not accept the fiat of international law in internal conflicts: No consensus, no law. Further, an insurgent movement had neither rights nor duties under customary international law until it was recognized as a belligerent. Even if the movement was an object of international concern, it was not a subject of international law. There being no reciprocity, the rules that bound the government in international conflicts failed to bind them in noninternational conflicts.

Both problems-the domestic jurisdiction argument and the lack of reciprocity-could be solved by agreement of nations to the contrary, as was done in article 3 of the 1949 Conventions, but such an intent would have to be stated expressly. If amendment of article 2 of the 1949 Conventions by article 1(4) of Protocol $I$ is doubtful, it is much less likely that article 1(4) also changed application of the customary international law of war, a subject not even mentioned in that paragraph.

Still applicable to CAR conflicts would be the Rights Covenant, the Genocide Convention, and common article 3 of the 1949 Conventions. The latter, termed a "Convention in miniature" for noninternational conflicts, distills some of the basic principles of customary international law applicable in international conflicts. ${ }^{167}$ Certainly no party to a CAR conflict can justify an atrocity on the ground that it is prohibited only in noninternational conflicts. These conventional sources of law afford little protection to infrastructure members from targeting during combat or for treatment after capture by the opposing party. Therefore, in many CAR conflicts there will be few specific rules for articles 72-79 to complement. We will now compare the treatment of infrastructure members under these articles with the treatment received by other civilians and with the treatment to which infrastructure members are entitled in traditional international conflicts.

\section{Protected Group}

Articles 72-79 of the Protocol deal with several subjects: their field of application, the status of refugees and stateless persons, reunion of dispersed families, fundamental guarantees, protection of women, protection and evacuation of children, and protection of journalists. For our purposes, the core is article 75, entitled "Fundamental Guarantees." Extensively rewritten at the

167. Pictet, IV Commentary, supra note 14 , at 34 . 
last session of the Diplomatic Conference, it was considerably improved over the earlier drafts. The approved language, however, raises some new questions.

The ostensible scope of article 75 is broad, covering persons "[i]n so far as they are affected by a situation referred to in Article 1 of the Protocol ... [and] who are in the power of a Party to the conflict and who do not benefit from more favorable treatment under the [1949] Conventions or this Protocol." What is the scope and test for "affected"? Are all inhabitants of a country undergoing rationing and curfews during a conflict "affected"? Must there be some logical relationship between the conflict and the fact that a person is in the hands of a party, or does article 75 set a minimum standard of civil rights (even for matters unrelated to the armed conflict) that benefits every person in the hands of a party? ${ }^{168}$

Since application depends in part on whether more favorable treatment is accorded under the 1949 Conventions or elsewhere in the Protocol, the extensive list of trial guarantees in paragraph 4 of article 75 raises a question. This list is similar, but not identical, to the list in article 72 of the Fourth Convention. Does a protected person gain the benefit of all rights on both lists, or is "more favorable treatment" determined by comparison of the entire Fourth Convention with article 75 of Protocol I?

\section{Criminal Punishment}

\section{a. Scope of Application of Judicial Guarantees}

The fourth paragraph of article 75 sets several procedural standards for trial of a person charged with "a penal offence related to the armed conflict." This formulation, while an improvement over earlier drafts, is still unnecessarily restrictive; it affords no protection to an individual convicted of an offense relating to occupation. A better formulation would have adopted the

168. Due to its own ambiguity, the Report of Committee III does not shed much light on this question:

At an early stage it was decided that the scope of the article should be restricted to persons affected by the armed conflict and further restricted to the extent that the actions by a Party in whose power they are so affect them. This is the purpose of the introductory clause of the paragraph.

ICRC, 15 ICRC, CDDH Official Records, supra note 154, at 458, 460 (CDDH/407/Rev. 1). The Report also points out that paragraphs 3-7 are further limited by their own terms to particular actions by the Party for actions, offenses, or reasons "related to the armed conflict." Id. Since paragraphs 3-7 extend their protection to individuals only if the actions taken against them by a Party relate to the armed conflict, the test for being "affected" by the armed conflict must be both different from and less in extent than the criteria of these paragraphs. Additionally, it would appear that the protections of paragraph 2 extend to all persons affected by an armed conflict, whether or not the prohibited actions are being taken against them for reasons related to the armed conflict. 
first paragraph of the article and referred to an offense related to "a situation referred to in Article 1 of this Protocol."

The list of judicial procedures required by article 75 is more detailed than the rights guaranteed by article 72 of the Fourth Convention; however, one of the most basic rights included in article 72 of the Fourth Convention-the right to counsel-is omitted from article 75 unless included by inference in the requirement for "generally recognized principles of regular judicial procedure" or subparagraph a's requirement that the accused be afforded "all necessary rights and means of defence." Though article 75 introduces an illustrative rather than an exclusive list of rights, it is doubtful if so basic and important a principle as the right to assistance of counsel can be inferred when it is not expressly stated.

b. Acts Committed Before Capture, Occupation, or Control of Territory

Also lacking is any counterpart to the limitation found in article 70 of the Fourth Convention that protected persons cannot be tried for "acts committed or for opinions expressed before the occupation, or during a temporary interruption thereof, with the exception of breaches of the laws and customs of war." Absence of this limitation permits a party to a CAR conflict to punish criminally those who supported its adversary during the conflict, even when that support was rendered in territory then controlled by the adversary. Once an internal disturbance reaches the level of an armed conflict, a case can be made that the laws of war rather than internal laws should govern relations between the adversaries. It is unlikely, however, that governments will be willing to surrender in advance the sanctions provided by their internal laws over rebels, or that victorious rebels will forgo retribution for the political acts of the former governors. Perhaps the most to be hoped for are the guarantees of article $75(4)$ (c) prohibiting collective penalties and limiting punishment to violations of the laws in force at the time the offense was committed.

In conclusion, no adverse distinction between infrastructure members and other civilians, whether they be insurgents captured by the government or civil servants in the hands of the insurgents, may be justified by the terms of article 75. Protection from criminal prosecution, however, is less than that enjoyed under the Fourth Convention in traditional international conflicts. Infrastructure members may be punished under local law for support given one faction in the CAR conflict even though they committed no breaches of international law.

\section{Conclusion}

Our concern has been the government's civil servant and his counterpart in the insurgent organization. Exploring the position of the civil servant in international conflicts as a basis for comparison, we found his legal protections 
identical to those enjoyed by other civilians. He was immune from attack so long as he refrained from acts directly causing death or destruction or otherwise directly harming the forces of his adversary. Support of his own country's armed forces was permissible. Commission of the prohibited acts, however, forfeited his legal immunity from military attack and exposed him to criminal punishment for violations of the law of war.

If his territory is occupied by the enemy or if he otherwise falls into their hands, the civil servant, like all other inhabitants of the occupied territory, may be subjected to internment or assigned residence if he represents an imperative threat to the security of the occupying power. Such a decision must be made on an individual, not a collective, basis. Criminal punishment may be given only if he violated the law of war prior to capture or violated the security regulations promulgated by the occupying power after occupation of the territory was effected. Again the civil servant shares this risk with all inhabitants of the occupied territory.

Throughout this structure of rules determining the position of governmental civil servants in international conflicts runs the influence of the correlative principles of military necessity and humanity. In each situation only that amount of force necessary to accomplish legitimate objectives is permitted. Where there is no compelling requirement under the principle of military necessity, use of force is prohibited by the principles of humanity.

This structure disintegrates when we turn to noninternational conflicts. Nations have given only the most grudging and limited consent for the application of international law to conflicts within their borders that do not involve another nation. Existing rules of international law applicable in noninternational conflicts are extremely limited in scope, vague in content, and frequently ignored in practice. One could argue that the rules fail to ban targeting of civilian supporters of factions in an internal conflict if some otherwise legitimate military advantage is rationally perceived. If a civilian supporter is captured by his enemy, he may be criminally punished for his past support activities so long as minimal judicial guarantees are granted. No rational connection between the actions taken against him by his captor and the captor's own security is required before his liberty may be restricted in a noncriminal manner.

If CAR conflicts truly are to be transformed from noninternational into international conflicts, attention must be paid to protection of the government's and the insurgents' infrastructures in three areas. First, the infrastructure members must be immunized from targeting unless they directly cause serious harm to the adversary. Support of one's own faction should not forfeit immunity. Protocol I would accomplish this goal.

Second, criminal punishment for support of one faction that does not involve violations of the law of war must be prohibited. Because the domestic 
political aspects of a CAR conflict would either prevent governments from accepting a binding legal obligation to this effect or, alternatively, preclude their ever admitting a conflict was CAR in nature, a compromise is needed: prosecutions for support of an opposing faction should be postponed until after conclusion of the hostilities. Then decisions whether to punish or grant amnesty can be made under cooler, less hectic circumstances than those prevailing during war. If the captured civilian supported the winning side, this postponement permits him to share the fruits of victory rather than being punished for violation of an allegiance no longer in effect. If it is necessary to restrict his movements in the interim, standards similar to those applicable for internment or assigned residence in international conflicts should govern the restrictions.

Third, such noncriminal restrictions on an individual's liberty as internment, assigned residence, house arrest, or other similar restrictions, must be related to a present serious threat to the security of the authority imposing the restriction. Additionally, the restrictions should be imposed only on an individual basis and should be subject to automatic and periodic review to determine if the circumstances originally impelling the restrictions continue to exist.

Protocol $I$ is deficient in both the second and third areas of protection, since it was drafted to complement the 1949 Conventions, many of whose provisions cannot apply to CAR conflicts. Nonetheless, Protocol I does represent a definite advance in protection for those found within its scope. 